Maurer School of Law: Indiana University

Digital Repository @ Maurer Law

1969

\title{
Judicial Review of Military Determinations and the Exhaustion of Remedies Requirement
}

\author{
Edward F. Sherman \\ Indiana University School of Law
}

Follow this and additional works at: https://www.repository.law.indiana.edu/facpub

Part of the Legal Remedies Commons, and the Military, War, and Peace Commons

\section{Recommended Citation}

Sherman, Edward F., "Judicial Review of Military Determinations and the Exhaustion of Remedies

Requirement" (1969). Articles by Maurer Faculty. 2261.

https://www.repository.law.indiana.edu/facpub/2261

This Article is brought to you for free and open access by the Faculty Scholarship at Digital Repository @ Maurer Law. It has been accepted for inclusion in Articles by Maurer Faculty by an authorized administrator of Digital Repository @ Maurer Law. For more information, please contact rvaughan@indiana.edu. 


\section{JUDICIAL REVIEW OF MILITARY DETERMINATIONS AND THE EXHAUSTION OF REMEDIES REQUIREMENT}

\section{Edward F.Sberman*}

CIVILIAN courts have traditionally acknowledged that they lack jurisdiction to interfere with determinations by the military concerning its own personnel. It has been asserted that this doctrine is required by the Constitution's delegation of powers over the armed forces to the executive and legislative branches ${ }^{1}$ and by the need for military autonomy in maintaining internal discipline and order. ${ }^{2}$ Buttressed by a line of Supreme Court decisions spanning the last hundred years, the doctrine was reaffirmed in 1962 by Chief Justice Warren in an address devoted to examining the principles of military justice:

[I]t is indisputable that the tradition of our country, from the time of the Revolution until now, has supported the military establishment's broad power to deal with its own personnel. The most obvious reason is that courts are ill-equipped to determine the impact upon discipline that any particular intrusion upon military authority might have. ${ }^{3}$

Despite the fact that the military has continued to enjoy relative autonomy over determinations affecting its own personnel, several areas have been carved out in which federal court review is permitted, particularly involving claims of demial of constitutional rights during the course of courts-martial ${ }^{4}$ and discharge proceedings. ${ }^{5}$ The Vietnam War has resulted in a rash of new suits challenging the doctrine of

"A.B., 1959, Georgetown University; M.A., 1967, University of Texas at El Paso, LL.B., 1962, Harvard University; Teaching Fellow, Harvard Law School, 196769; Assistant Professor of Law, Indiana University School of Law, 1969-70. Mr. Sherman served in the United States Army from 1965 to 1967 and holds a commission in the United States Army Reserve, Judge Advocate General's Corps.

1 See W. Winthrop, Murtary LaW and Precedents 49 (2d ed. 1920).

2 See Barker, Military Law-A Separate System of Jurisprudence, 36 U. CrN. L. Rev. 223 (1967); Fratcher, Review by the Civil Courts of Judgments of Federal Military' Tribunals, 10 OHro St. L.J. 271 (1949); Comment, God, The Amy, and Judicial Review: The In-Service Conscientious Objector, 56 Calr. L. REv. 379 (1968).

3 Warren, The Bill of Rigbts and the Military, 37 N.Y.U.L. Rev. 181, 187 (1962).

4 E.g., Burns v. Wilson, 346 U.S. 137 (1953).

5 E.g., Harmon v. Brucker, 355 U.S. 579 (1958) (per curiam). 
nonreviewability by attempting to obtain federal court relief from a variety of military determinations. Suits have been filed in the last two years to require a discharge on the grounds that the military improperly determined conscientious objector status, ${ }^{6}$ medical fitness, ${ }^{7}$ and personal hardship, ${ }^{8}$ to declare void the activation of reserve and national guard units $^{9}$ and individuals, ${ }^{10}$ to prevent transfer of units ${ }^{11}$ and individuals ${ }^{12}$

6 E.g., Hammond v. Lenfest, 398 F.2d 705 (2d Cir. 1968); Brown v. McNamara, 387 F.2d 150 (3d Cir. 1967), cert. denied, 390 U.S. 1005 (1968), aff'g 263 F. Supp. 686 (D.N.J. 1967); Noyd v. McNamara, 378 F.2d 538 (10th Cir.), cert. denied, 389 U.S. 1022, aff'g 267 F. Supp. 701 (D. Colo. 1967); Cooper v. Barker, 291 F. Supp. 952 (D. Md. 1968); Gann v. Wilson, 289 F. Supp. 191 (N.D. Cal. 1968).

7 E.g., Petition of Bank, 290 F. Supp. 120 (N.D. Cal. 1968); Weber v. Clifford, 289 F. Supp. 960 (D. Md. 1968); Rank v. Gleszer, 288 F. Supp. 174 (D. Colo. 1968).

8 E.g., United States ex rel. Sclionbrun v. Commanding Officer, 403 F.2d 371 (2d Cir. 1968), reconsideration of denial of stay denied, $89 \mathrm{~S}$. Ct. 609 (1969) (Douglas, J., dissenting).

${ }^{9}$ E.g., Felberbaum v. MacLaughlin, 402 F.2d 57 (4tb Cir. 1968); McArthur v. Clifford, 402 F.2d 58 (Sth Cir.), stay denied, 393 U.S. 810, cert. denied, 393 U.S. 1002 (1968) (Douglas, J., dissentiug); Morse v. Boswell, $401 \mathrm{~F} .2 \mathrm{~d} 544$ (4tl1 Cir.), stay denied, 393 U.S. 802 (1968) (Douglas, J., dissenting), cert. denied, 89 S. Ct. 687 (1969) (Douglas, J., dissenting); McAbee v. Martinez, 291 F. Supp. 77 (D. Md.), injzonctive relief denied, 393 U.S. 904 (1968); Sullivan v. Cushman, 290 F. Supp. 659 (D. Mass. 1968) (three-judge court) (unsuccessful action by army reservists to prevent activation and orders to Vietnam on grounds of violation of reserve contract and denial of due process for failure to provide individual hardship liearings), stay denied, 393 U.S. 810 (1968) (Douglas, J., dissenting); Linsalata v. Clifford, 290 F. Supp. 338 (S.D.N.Y. 1968); Goldstein v. Clifford, 290 F. Supp. 275 (D.N.J. 1968).

${ }^{10}$ E.g., Fox v. Brown, 402 F.2d 837 (2d Cir.), aff'g 286 F. Supp. 855 (S.D.N.Y. 1968); Weber v. United States, 288 F. Supp. 491 (E.D. Pa. 1968); Even v. Clifford, 287 F. Supp. 334 (S.D. Cal. 1968); Winters v. United States, 281 F. Supp. 289 (E.D.N.Y.), aff'd per curiazn, 390 F.2d 879 (2d Cir.), stay denied, 390 U.S. 993, reconsideration of denial of stay denied, 391 U.S. 910, cert. denied, 89 S. Ct. 188 (1968) (unsuccessful action to prevent ordering to active duty for noncompliance witl reserve obligations on grounds contract obligations changed); Winters v. United States, $89 \mathrm{~S}$. Ct. 57 (1968) (stay granted by Justice Douglas to prevent reactivation second time pending decision on merits by 9th Cir.); Ali v. United States, 289 F. Supp. 530 (C.D. Cal. 1968); Gion v. McNamara, Civil No. 76-1563-EC (C.D. Cal. Jan. 9, 1969) (order to active duty for more than 45 days because of unsatisfactory participation in reserves held in violation of contract and constitutional rights).

11 E.g., Morse v. Boswell, 401 F.2d 544 (4th Cir.), stay denied, 393 U.S. 802 (1968) (Douglas, J., dissenting), cert. denied, 89 S. Ct. 687 (1969) (Douglas, J., dissenting); McAbee v. Martinez, 291 F. Supp. 77 (D. Md.), injunctive relief denied, 393 U.S. 904 (1968); Sullivan v. Cushman, 290 F. Supp. 659 (D. Mass. 1968); Johnson v. Powell, 89 S. Ct. 250 (1968) (application for stay denied) (Douglas, J., dissenting, objecting that National Guard petitioners were "spirited out of the country" to Vietuam by military and thereby deprived of hearing).

12 Smith v. Ritchey, $89 \mathrm{~S}$. Ct. 54 (1968) (stay granted) (stay issued by Douglas, J., to prevent transfer of serviceman to Formosa under orders issued after he organized 
overseas, to rescind orders concerning duty assignments, ${ }^{13}$ and to prevent the court-martial of servicemen. ${ }^{14}$ Most of these suits have foundered on the threshold question of jurisdiction, with federal courts denying jurisdiction in reliance on the traditional doctrine of nonreviewability or on a finding that the complainant failed to exhaust military remedies. However, last June a decision was handed down by the Second Circuit which appears to have made a significant breach in the old nonreviewability doctrine and to have liberalized the requirement of exhaustion of remedies. In Hammond $v$. Lenfest, ${ }^{15}$ the Second Circuit reversed the district court's determination that it lacked jurisdiction to consider a reservist's application for a writ of habeas corpus, and ordered him discharged from the Navy unless evidence was introduced at rehearing to provide a basis in fact for denial of his request for a conscientious objector discliarge. ${ }^{16}$ In holding that a serviceman is entitled to federal court review of a military administrative determination concerning a request for discharge, without requiring that he exhaust his military remedies through a courtmartial proceeding, the Second Circuit rejected the stringent exhaustion

peace march); Earl v. Cushman, Misc. Civil No. 68-1164-J (D. Mass. Dec. 18, 1968) (denial of temporary restraining order to prevent shipment of officer to Vietnam, such shipment allegedly in violation of Army regulation that he must be retained in unit upon filing application for conscientious objector discharge); Bates v. Commanding Officer, Misc. Civil No. 68-64-F (D. Mass. Oct. 29, 1968) (habeas corpus action to require discharge on grounds no basis in fact for denial of conscientious objector status resulting in voluntary return of petitioner by military to jurisdiction of district court pending court determination and appeal), rev'd, No. 7241 (1st Cir. Jan. 7, 1969), writ denied on remand, Misc. Civil No. 68-64-F (D. Mass. March 14, 1969), appeal pending No. 7315 (1st Cir. 1969).

${ }^{13}$ E.g., Noyd v. McNamara, 378 F.2d 538 (10th Cir.), cert. denied, 389 U.S. 1022, aff'g 267 F. Supp. 701 (D. Colo. 1967); Noyd v. Bond, 402 F.2d 441 (10th Cir.), rev'g 285 F. Supp. 785 (D.N.M.), non-incarcerated status granted, 89 S. Ct. 478 (1968), cert. granted, 89 S. Ct. 692 (1969).

${ }^{44}$ E.g., In re Kelly, 401 F.2d 211 (5th Cir. 1968); Levy v. McNamara, Civil No. 953-67 (D.D.C. May 9, 1967), aff'd sub nom. Levy v. Corcoran, 389 F.2d 929 (D.C. Cir.) (Bazelon, J., dissenting), stay denied, 387 U.S. 915, cert. denied, 389 U.S. 960 (1967) (unsuccessful attempt to convene three-judge court and enjoin convening of courtmartial on grounds of chilling effect on first amendment rights).

15398 F.2d 705 (2d Cir. 1968).

16 Two and a half months after its decision in Hammond, the Second Circuit issued a new per curiam opinion on petition for rehearing. The court stated that because the armed services had adopted new regulations concerning discharge of conscientious objectors, the case should be sent back to the Department of the Navy to be processed in accordance with the new regulations. 398 F.2d 705, 718 (2d Cir. 1968). For discussion of the effect of this order upon the original opinion, see text at note 202 infra. 
rule which had been adopted in recent decisions by other circuits. ${ }^{17}$ Other courts have now followed Hammond by accepting jurisdiction in both conscientious objector discharge ${ }^{18}$ and non-discharge cases. ${ }^{19}$ This article will re-examine the doctrine that federal courts lack jurisdiction to review military determinations concerning personnel in light of Hammond and its progeny, and will consider what standards are now required for reviewability.

\section{Historical Basts for Dental of Feberat Court Jurisdiction to Review Military Determinations}

A military determination affecting personnel can be made either by a court-martial decision or a non-court administrative determination. The historical development of nonreviewability differs somewhat between the two categories.

\section{Review of Court-Martial Decisions}

With respect to review of court-martial decisions, American law has followed the English concept that military courts provide an autonomous system of jurisprudence which, due to the exigencies of military life and the necessity for discipline, should not be interfered with by the civil authorities. ${ }^{20}$ Article I, section 8 of the Constitution gives Congress the power to "make Rules for the Government and Regulation of the land and naval forces." It is this clause, together with the other legislative and executive powers over the armed forces, ${ }^{21}$ that has served as a basis for the holding that the military courts are not

17 See Brown v. McNamara, 387 F.2d 150 (3d Cir. 1967), cert. denied, 390 U.S. 1005 (1968), aff'g 263 F. Supp. 686 (D.N.J. 1967); Noyd v. McNamara, 378 F.2d 538 (10th Cir.), cert. denied, 389 U.S. 1022, aff'g 267 F. Supp. 701 (D. Colo. 1967).

18 Cooper v. Barker, 291 F. Supp. 952 (D. Md. 1968); Gann v. Wilson, 289 F. Supp. 191 (N.D. Cal. 1968); Mandel v. Dayton, Civil No. 68-2695 (S.D.N.Y. Sept. 3, 1968).

${ }^{19}$ Smith v. Resor, 406 F.2d 141 (2d Cir. 1969) (habeas corpus to prevent activation resulting from unsatisfactory attendance ratings on account of long hair despite regulations permitting it); In re Kelly, 401 F.2d 211 (5th Cir. 1968).

20 See W. Winthrop, Military Law and Precedents 49 (2d ed. 1920). See generally Comment, God, the Army, and Judicial Review: The In-Service Conscientious Objector, supra note 2, which contains an excellent discussion of the nonreviewability doctrine.

21 U.S. Consr. art. II, $\$ 2$ provides: "The President shall be Commander in Chief of the Army and Navy of the United States, and of the Militia of the several States, when called into the actual Service of the United States ...." U.S. Consr. art. I, $\S 8$ gives Congress the power: "To declare War ... To raise and support Armies . . . To provide and maintain a Navy; To make Rules for the Government and Regulation of the land and naval Forces...." 
Article III courts, but are agencies of the executive branch established pursuant to Articles I and II. ${ }^{22}$ Furthermore, Dynes v. Hoover ${ }^{23}$ established in the mid-nineteenth century that the civil courts have no power to interfere with courts-martial and that court-martial decisions are not subject to civil court review. The Supreme Court also eschewed jurisdiction to review by writ of certiorari the proceedings of a military commission. ${ }^{24}$

The unavailability of civil court review of court-martial decisions did not, however, extend to habeas corpus jurisdiction. Indeed, the policy reasons for preserving federal habeas corpus jurisdiction as a last remedy for a petitioner in unlawful custody ${ }^{25}$ were as ancient and compelling as the policy of noninterference with the military, and when the two interests collided, habeas corpus was the victor. ${ }^{26}$ By the latter part of the nineteenth century, it had been established that habeas corpus was the exclusive means of obtaining review of military determinations, ${ }^{27}$ a doctrine which has only recently been modified to permit collateral review based on federal question jurisdiction, declaratory judgment, and mandamus. ${ }^{28}$

22 Kurtz v. Moffitt, 115 U.S. 487 (1885); Dynes v. Hoover, 61 U.S. (20 How.) 65 (1858); Ex parte Dickey, 204 F. 322 (D. Me. 1913); United States v. Maney, 61 F. 140 (C.C.D. Minn. 1894).

2361 U.S. (20 How.) 65 (1858).

24 Ex parte Vallandigham, 68 U.S. (1 Wall.) 243 (1864).

25 Habeas Corpus was termed the "great writ" in Justice Marshall's day, Ex parte Bollman, 8 U.S. (4 Cranch) 75, 95 (1807), and has often been called "the great writ of liberty'," Burns v. Wilson, 346 U.S. 137, 148 (1953) (Frankfurter, J.); Fay v. Noia, 372 U.S. 391 (1963). See C. Wrighr, Federal Courts 177-186 (1963).

26 In Ex parte Milligan, 71 U.S. (4 Wall.) 2 (1866), the Supreme Court held that federal courts have habeas corpus jurisdiction to examine unlawful detention imposed by court-martial. After this decision, Congress passed the Act of March 27, 1868, ch. 34, 15 Stat. 44, removing appellate jurisdiction in habeas corpus cases froin the Supreme Court, apparently in an attempt to remove the opportunity of the Court to invalidate the reconstruction military governments' provisions. See J. BuRgess, ReconStruction AND the Constitution 197 (1902); 2 C. Warren, The Supreme Court iN United States History 455 (1937 ed.); Wooldridge, Book Review, 55 VA. L. Rev. 569 (1969). The Act was upheld in Ex parte McCardle, 74 U.S. (7 Wall.) 506 (1869), but was later held to leave intact the power of the Supreme Court to review denial of a writ of habeas corpus on a petition for certiorari. Ex parte Yerger, 75 U.S. (8 Wall.) 85 (1869). See H. M. Hart \& H. Wechsler, The Federal Courts and the Federat. SXSTEN 290-94 (1953).

27 See Ex parte Reed, 100 U.S. 13 (1879).

28 "Federal question" jurisdiction, pursuant to 28 U.S.C. $\$ 1331$ (1964), would appear to provide the vehicle for federal court jurisdiction in most cases challenging a military determination, provided that the matter in controversy exceeds $\$ 10,000$. Other bases for jurisdiction are mandamus pursuant to 28 U.S.C. $\$ 1361$ (1964), Ashe v. 
The scope of habeas corpus review of military determinations has always been severely restricted. It was originally limited to cases of actual confinement ${ }^{29}$ and restricted to the issue of whether the courtmartial had jurisdiction over the person tried and the offense charged. ${ }^{30}$ However, since habeas corpus review could inquire into the lawfulness of military jurisdiction over the person, it was early held that the writ would lie to obtain the release or discharge of one unlawfully inducted. ${ }^{31}$ Thus, habeas corpus actions have been used to obtain the release of a petitioner who refused to take the oath of induction on the grounds that he was never lawfully subject to military jurisdiction ${ }^{32}$ and, in recent cases, to secure discharge where a draft board wrongfully denied an exempt classification, ${ }^{33}$ failed to follow proper induction procedures, ${ }^{34}$ or gave erroneous and misleading information concerning the right to appeal a classification. ${ }^{35}$

McNamara, 355 F.2d 277 (1st Cir. 1965); declaratory judgment pursuant to 28 U.S.C. $\S 2201$ (1964) and Fed. R. Civ. P. 57, Gallagher v. Quinn, 363 F.2d 301 (D.C. Cir.), cert. denied, 385 U.S. 881 (1966); suit for back pay in the Court of Claims, Augenblick v. United States, 377 F.2d 586 (Ct. Cl. 1967), rev'd, 89 S. Ct. 528 (1969) (leaves open question whether collateral attack on court-martial judgments may be made in the Court of Claims). Injunctive relief is sought under FED. R. CIv. P. 65 and the general equity jurisdiction of the federal courts. It is uncertain whether the Administrative Procedure Act, 5 U.S.C. $\$ \$ 701-06$ (Supp. II, 1967), amending 5 U.S.C. $\$ 1009$ (1964), applies to the military. See United States ex rel. Schonbrun v. Commanding Officer, 403 F.2d 371, 375 n.2 (2d Cir. 1968), reconsideration of denial of stay denied, 89 S. Ct. 609 (1969); Jaffe, The Exbaustion of Administrative Remedies, 12 Burr. L. Rev. 327, $327-34$ (1963). 29 Wales v. Whitney, 114 U.S. 564 (1885); United States ex rel. McKiever v. Jack, 351 F.2d 672 (2d Cir. 1965); Petition of Green, 156 F. Supp. 174 (S.D. Cal. 1957), appeal dismissed as moot, $264 \mathrm{~F} .2 \mathrm{~d} 63$ (9th Cir. 1959). But see United States ex rel. Schonbrun v. Commanding Officer, 403 F.2d 371, 373 (2d Cir. 1968), reconsideration of denial of stay denied, 89 S. Ct. 609 (1969); Hammond v. Lenfest, 398 F.2d 705, 710-12 (2d Cir. 1968); Ex parte Fabiani, 105 F. Supp. 139 (E.D. Pa. 1952); United States ex rel. Steinberg v. Graham, 57 F. Supp. 938, 941-42 (E.D. Ark. 1944), appeal dismissed per stipulation, 149 F.2d 647 (8th Cir. 1945); United States ex rel. Altieri v. Flint, 54 F. Supp. 889 (D. Conn. 1943), aff'd, 142 F.2d 62 (2d Cir. 1944).

30 See generally W. Aycock \& S. Wurfed, Mritary Law Under the Uniform Code of Military Justice 314-29 (1955).

31 In re Grimley, 137 U.S. 147 (1890); In re Morrissey, 137 U.S. 157 (1890); Stingle's Case, 23 F. Cas. 107 (No. 13,458) (E.D. Pa. 1863); United States ex rel. Turner v. Wright, 28 F. Cas. 798 (No. 16,778) (W.D. Pa. 1862).

32 Billings v. Truesdell, 321 U.S. 542 (1944). See United States ex rel. Roberson v. Keating, 121 F. Supp. 477 (N.D. Ill. 1949).

33 E.g., Striker v. Resor, 283 F. Supp. 923 (D.N.J. 1968). But see Pickens v. Cox, 282 F.2d 784 (10th Cir. 1960).

34 United States ex rel. Wilkerson v. Commanding Officer, 286 F. Supp. 290 (S.D.N.Y. 1968); United States ex rel. Caputo v. Sharp, 282 F. Supp. 362 (E.D. Pa. 1968).

35 Powers v. Powers, 400 F.2d 438 (5th Cir. 1968). 
The limitation of military habeas corpus review to questions of jurisdiction was expanded only slightly at the turn of the nineteenth century to permit inquiry into whether the court-martial had exceeded its porver in imposing sentence, ${ }^{36}$ and whether the court-martial was legally constituted. ${ }^{37}$ As late as 1950, the Supreme Court could still state in Hiatt $v$. Brown that "[i]t is well settled that "by babeas corpus the civil courts exercise no supervisory or correcting power over the proceedings of a court-martial .... The single inquiry, the test, is jurisdiction." " 38 However, Hiatt proved to be a last declaration of orthodoxy, for during the 1930's and 1940's there had been a steady expansion in the scope of federal habeas corpus review of state court decisions, ${ }^{39}$ and by the early 1950's similar pressures were generated regarding military habeas corpus. In 1953, in Burns $v$. Wilson, ${ }^{20}$ the Court accepted the contention that federal courts, on considering petitions for writs of habeas corpus, may review claims of denial of due process which the military had manifestly refused to consider in courtsmartial. Since Burns v. Wilson, the scope of military habeas corpus has included inquiry into whether the court-martial had proper jurisdiction of the person and the offense, whether the accused was accorded due process of law pursuant to the Uniform Code of Military Justice, and whether the military tribunal gave fair and full consideration to all procedural safeguards necessary to a fair trial under military law. ${ }^{41}$

36 Carter v. McClaughry, 183 U.S. 365 (1902).

37 McClaughry v. Deming, 186 U.S. 49 (1902).

38339 U.S. 103, 111 (1950).

39 See Note, The Freedom Writ-The Expanding Use of Federal Habeas Corpus, 61 HARv. L. Rev. 657, 660 (1948). See generally H. M. HART \& H. WECHSLER, supra note 26, at 1238.

40346 U.S. 137 (1953).

41 This interpretation of the scope of habeas corpus review after Burns was stated by the Tenth Circuit in Gorko v. Commanding Officer, 314 F.2d 858, 859 (10th Cir. 1963), and has been followed in a number of subsequent Tenth Circuit cases. E.g., Kennedy v. Commandant, 377 F.2d 339 (10th Cir. 1967); Palomera v. Taylor, 344 F.2d 937 (10th Cir.), cert. denied, 382 U.S. 946 (1965). However, there have been a number of different interpretations of the scope of review after Burns. See Katz \& Nelson, The Need for Clarification in Military Habeas Corpus, 27 OHI ST. L.J. 193 (1966). The inquiry into whether the accused was accorded due process of law has generally been interpreted as including only those rights incident to military due process. United States v. Clay, 1 U.S.C.M.A. 74, 1 C.M.R. 74 (1951), viewed the term "military due process" as referring only to those rights, derived from Congress rather than the Bill of Rights, which are requisite to fundamental fairness in a court-martial, apparently as defined in the Uriform Code of Military Justice [hereinafter referred to as UCMI] Art. 64, 10 U.S.C. \$ 864 (1964). However, Uuited States v. Jacoby, 11 U.S.C.M.A. 428, 430-31, 29 C.M.R. 244, 246-47 (1960), stated that "the protections of the Bill of Rights, except those 


\section{Review of Administrative Determinations}

The second type of military determination affecting personnel-the non-judicial administrative decision-has undergone a slightly different historical development with respect to the doctrine of nonreviewability. Throughout the nineteenth century, military administrative determinations were considered "executive" actions and hence immune from court review. ${ }^{42}$ This rule, despite its questionable rationale, ${ }^{43}$ prevailed until the development of modern concepts of administrative law in the twentieth century. In 1902 the Supreme Court in American School of Magnetic Healing v. McAnnulty ${ }^{44}$ decided that courts have jurisdiction to review the acts of an administrative department (the Post Office) and thus abolished the "executive" immumity of military administrative determinations. Subsequently, the justification cited for nonreview of military administrative determinations was based upon the concept that because of the traditional and constitutional separation of military and civil authority, civilian courts have no power to interfere with the military sphere. ${ }^{45}$

The doctrine of nonreviewability of military administrative determinations was largely developed in suits seeking review of discharges. Discharge cases are a paradigm for the doctrine of nonreviewability ${ }^{46}$

which are expressly or by necessary imphication inapplicable, are available to members of our armed forces." In re Stapley, 246 F. Supp. 316 (D. Utah 1965), is an example of a liberal interpretation of Burns, and holds that the district court could determine on habeas corpus a claim of denial of the sixth amendment right to counsel in a special court-martial, although such right had not previously been held to be necessary for military due process, United States v. Culp, 14 U.S.C.M.A. 199, 33 C.M.R. 411 (1963). But see Kennedy v. Commandant, supra; LeBallister v. Warden, 247 F. Supp. 349 (D. Kan. 1965).

42 See Decatur v. Paulding, 39 U.S. (14 Pet.) 497 (1840), in which the Supreme Court held that it had no jurisdiction to review an administrative determination of the Secretary of the Navy as to the applicability of a federal pension statute to a member of the military, because the action of the Secretary, like any other executive department, was immune from review.

43 The rule is criticized in $3 \mathrm{~K}$. Davis, Administratrve Law Treatise $\$ 23.11-.12$ (1958); L. Jaffe, Judicial Control of Administrative Action 181 (1965), and indeed is no longer followed. See Dismuke v. United States, 297 U.S. 167 (1936) (granting review of administrative decision rejecting claim for annuity on question of law).

44187 U.S. 94 (1902).

45 This position was taken largely in rehance on the decision in Dynes v. Hoover, 61 U.S. (20 How.) 65 (1858), see text at note 23 supra, and subsequent court-martial cases.

46 "It was almost exclusively against the background of these numerous disputes over the fact or type of discharge that the Willoughby rule developed during the first half of the twentieth century." Comment, God, the Army, and Judicial Review: The In-Service Conscientious Objector, supra note 2, at 419. See text at note 63 infra. 
for they involve a particularly vital concern of the military-its ability to meet manpower requirements-which is frequently cited as a justification for giving the military a free hand over its personnel. ${ }^{47}$ Since the military must rely on recruitment and the draft for its manpower, it is of some importance that it possess the power to require, grant, or withhold discharges and to condition them as honorable or less than honorable. The first discharge case to reach the Supreme Court after McAnnulty was Reaves $v$. Ainswort $b^{48}$ in which an officer sought review of an examination board proceeding that had retired him involuntarily. The Court held that it lacked jurisdiction to review due process claims in discharge proceedings, emphasizing the military's autonomous nature rather than its executive immunity. Subsequent decisions $^{49}$ after World War I rehed upon the Dynes50 view of the military's historical imnunity from civilian review in holding that discharge actions were not reviewable.

Although the nonreviewability of discharge determinations has often been stated in absolute terms, ${ }^{51}$ significant modifications have been effected in this area. The first breaches in the nonreviewability doctrine occurred in cases seeking correction of a discharge after the fact, probably because such suits offer less threat of interference with military operations. In Patterson v. Lamb, ${ }^{52}$ the petitioner brought suit twentynine years after receiving a World War I "discharge from the draft" (which disqualified him from veterans' benefits) to compel the Army to issue him a certificate of honorable discharge. The Supreme Court refused the relief, but only after accepting jurisdiction and reviewing the case on the merits. In Harmon v. Brucker, ${ }^{53}$ decided in 1958, the Court made a more distinct break with the nonreviewability doctrine. Harmon had been given an undesirable discharge as a security risk because of his allegedly subversive activities prior to induction, despite an excellent

47 See, e.g., Winters v. United States, 391 U.S. 910 (application for stay denied mem.) (Harlan, J.), cert. denied, 393 U.S. 896 (1968); Brown v. McNamara, 263 F. Supp. 686 (D.N.J.), aff'd, 387 F.2d 150 (3d Cir. 1967), cert. denied, 390 U.S. 1005 (1968).

48219 U.S. 296 (1911).

49 United States ex rel. French v. Weeks, 259 U.S. 326 (1922); United States ex rel. Creary v. Weeks, 259 U.S. 336 (1922).

50 See text at note 23 supra.

51 See, e.g., Gentila v. Pace, 193 F.2d 924 (D.C. Cir. 1951), cert. denied, 342 U.S. 943 (1952); Davis v. Woodring, 111 F.2d 523 (D.C. Cir. 1940); Marshall v. Wyman, 132 F. Supp. 169 (N.D. Cal. 1955); Nordmann v. Woodring, 28 F. Supp. 573 (W.D. Okla. 1939).

52329 U.S. 539 (1947).

53355 U.S. 579 (1958) (per curiam). 
service record. He brought suit to require the Secretary of the Army to void the undesirable discharge and issue an honorable discharge. The Court relied upon McAnnulty and, by analogy, upon Burns v. $W_{i l s o n}{ }^{54}$ in holding that federal courts have jurisdiction to consider claims that the Secretary has exceeded his statutory authority by basing the undesirable discharge on pre-induction conduct. A recent D.C. Circuit opinion, Kennedy v. Secretary of the Navy, ${ }^{55}$ has further extended Harmon by permitting a suit to void a dishonorable discharge that was issued because the petitioner was a member of the Communist Party while he was in the service.

Further inroads on the nonreviewability doctrine have been made in renedial discharge cases involving claims that a discharge was based on a constitutionally defective court-martial. In Asbe $v$. McNamara, ${ }^{56}$ the First Circuit ruled that the Secretary of Defense had a duty to change a seventeen-year-old dishonorable discharge to honorable because it was adjudged in a court-nuartial which violated petitioner's constitutional rights. ${ }^{57}$ Two related Court of Claims decisions ${ }^{58}$ voided the dismissals of two officers because the Secretary failed to provide regulation-required hearings after the officers' court-nuartial convictions (upon which the dismissals were based) were set aside. In a slightly different context, but also involving correction of military records after the fact, a federal district court in Robson v. United States ${ }^{59}$ recently vacated a previously effected court-martial conviction because

54 See text at note 40 supra.

55401 F.2d 990 (D.C. Cir. 1968). See also Bland v. Connally, 293 F.2d 852 (D.C. Cir. 1961); Davis v. Stahr, 293 F.2d 860 (D.C. Cir. 1961).

56355 F.2d 277 (1st Cir. 1965).

57 In Davies v. Clifford, 393 F.2d 496 (1st Cir. 1968), aff'g 275 F. Supp. 278 (D.N.H. 1967), petitioner sued in federal court after an unsuccessful petition to the Court of Military Apeals to have a 16-year-old court-martial conviction vacated because of errors which, it was admitted, violated his constitutional rights. The First Circuit ruled that it had no jurisdiction to make a direct review of a court-martial conviction and distinguished its previous decision in $A s h e$ as a case involving only "collateral administrative relief" in voiding a punitive discharge, while in Davies the petitioner sought direct review of a decision of the Court of Military Appeals. The court specifically rejected the language in Augenblick v. United States, 377 F.2d 586, 591-93 (Ct. Cl. 1967), rev'd, 89 S. Ct. 528 (1969), and Gallagher v. Quinn, 363 F.2d 301 (D.C. Cir.), cert. denied, 385 U.S. 881 (1966), which implied jurisdiction to review action of the Court of Military Appeals other than by writ of habeas corpus.

58 Hamlin v. United States, 391 F.2d 941 (Ct. Cl. 1968); Motto v. United States, 348 F.2d 523 (Ct. Cl. 1965).

59279 F. Supp. 631 (E.D. Pa. 1968). 
subsequent facts indicated that it had been obtained with illegally seized evidence.

Cases seeking court action affecting the discharge of one still in the military involve greater interference with day-to-day military operations, but here too there have been inroads on the nonreviewability doctrine. In Reed $v$. Franke, ${ }^{60}$ a serviceman with 18 years of service sued to enjoin the Navy from administratively discharging him as an alcoholic because of two courts-martial concerning his driving while under the influence of intoxicants (He had the misfortune of colliding with a Vice Admiral's automobile.). The court stated that while there can be no direct judicial review of the administrative proceedings, the procedure involved will be subject to review where there is a substantial claim that prescribed military procedures violate constitutional rights. ${ }^{61}$ Despite this statement, however, the court found that because the petitioner had not exhausted available military remedies, his claim could not be heard. Further extending the scope of available civilian relief, Schwartz v. Covington ${ }^{62}$ held that a pending undesirable discharge based on alleged homosexual activities could be enjoined until the enlisted man involved sought relief from various review boards within the service.

Although genuine inroads have thus been made in the nonreviewability doctrine with respect to discharge cases, the doctrine is still closely followed with regard to military determinations concerning orders, duty assignments, personnel status, and other non-discharge administrative determinations. The principal authority for an absolute rule of nonreviewability in such cases is the Supreme Court's 1953 decision in Orloff $v$. Willoughby. ${ }^{63}$ Orloff, a doctor who had been drafted, brought a habeas corpus suit to require the Army to assign him to medical duties and award him a commission which had been denied because of his refusal to answer certain questions concerning prior Communist Party affiliations. Despite a limited fact situation (The Army had voluntarily assigned him to medical duties before the case reached the Supreme Court, thus weakening his claim that the malassignment caused a substantial loss of rights.), the Court expressed its decision in absolute terms. It found that although the Doctors' Draft

60297 F.2d 17 (4th Cir. 1961).

61 Id. at 19-21.

62341 F.2d 537 (9th Cir. 1965).

63345 U.S. 83 (1953). 
Act entitled Orloff to a medical assignment, the Court had no power to review the Army determination preventing such an assignment:

[I]t is not within the power of this Court by habeas corpus to determine whether specific assignments to duty fall within the basic classification of petitioner. ... While the courts have found occasion to determine whether one has been lawfully inducted and is therefore within the jurisdiction of the Army and subject to its orders, we have found no case where this Court has assumed to revise duty orders as to one lawfully in the service. ${ }^{64}$

The Court went on to express the policy behind the doctrine of nonreviewability in langnage which has been repeated in nearly every subsequent military review case:

[J] udges are not given the task of running the Army. . . . The military constitutes a specialized community governed by a separate discipline from that of the civilian. Orderly government requires that the judiciary be as scrupulous not to interfere with legitimate Army matters as the Army must be scrupulous not to intervene in judicial matters. ${ }^{65}$

Although the broad proscription in Orloff has not been followed in the discharge cases discussed above, and although further doubt has now been raised as to the doctrine's applicability in attacking military personnel determinations on certain limited grounds, ${ }^{60}$ the strict rule of nonreviewability has been applied in suits involving military orders for a particular assignment or a particular location (even if overseas), ${ }^{67}$

64 Id. at 93-94.

$65 \mathrm{Id}$.

66 E.g., cases attacking determinations as exceeding the statutory authority of the military, Smith v. Resor, 406 F.2d 141 (2d Cir. 1969); Thompson v. Clifford, 37 U.S.L.W. 2349 (D.C. Cir. Dec. 13, 1968); United States ex rel. Guagliardo v. McElroy, 259 F.2d 927, 929 (D.C. Cir. 1958), aff'd, 361 U.S. 281 (1960); Noyd v. Bond, 285 F. Supp. 785 (D.N.M.), rev'd, 402 F.2d 441 (10th Cir.), non-incarcerated status granted, 89 S. Ct. 478 (1968), cert. granted, 89 S. Ct. 692 (1969); Winters v. United States, 281 F. Supp. 289 (E.D.N.Y.), aff'd per curiam, 390 F.2d 879 (2d Cir.), stay denied, 391 U.S. 910, cert denied, 393 U.S. 896 (1968); Fox v. Brown, 402 F.2d 837 (2d Cir.), aff'g 286 F. Supp. 855 (S.D.N.Y. 1968) (dicta); Robson v. United States, 279 F. Supp. 631 (E.D. Pa. 1968) (dicta), or as violating first amendment rights, Smith v. Ritchey, 89 S. Ct. 54 (1968); Howe v. Clifford, No. $622-68$ (D.D.C. 1968).

67 Mora v. McNamara, 389 U.S. 934 (1967); Brown v. McNamara, 387 F.2d 150 (3d Cir. 1967), cert. denied, 390 U.S. 1005 (1968), aff'g 263 F. Supp. 686 (D.N.J. 1967); Noyd v. McNamara, 378 F.2d 538 (10th Cir.), cert. denied, 389 U.S. 1022, aff'g 267 
discretionary administrative determinations such as whether an individual is physically fit for overseas duty ${ }^{68}$ or whether a unit has received adequate training for assignment to a war zone, ${ }^{69}$ and referral of charges to court-martial. ${ }^{70}$ These decisions, generally involving the assignments and status of servicemen, are unlike the discharge cases in that they employ a mechanical apphication of the nonreviewability doctrine rather than a balancing of such relevant considerations as the nature of the petitioner's challenge to the military determination, the degree of anticipated interference with the military, the extent to which military expertise is actually involved, and the potential injury to the petitioner if review is refused.

The large number of suits during the Vietnam War period seeking relief from military determinations have put the federal courts in the difficult position of having to make decisions on highly sensitive political issues. The Supreme Court has rather consistently refused to grant certiorari in cases involving controversial questions relating to the conduct of the war and the operation of the military, ${ }^{71}$ but the lower courts cannot avoid the issues as easily. Some courts have simply applied the strict doctrine of nonreviewability to nilitary cases, sunmarily denying jurisdiction. ${ }^{2}$ However, the erosion of the nonreviewability doctrine has made such absolute denials of jurisdiction difficult

F. Supp. 701 (D. Colo. 1967); Luftig v. McNamara, 373 F.2d 664 (D.C. Cir.), cert. denied, 387 U.S. 945 (1967); Cooper v. United States, 403 F.2d 71 (10th Cir. 1968) (dicta); United States v. Mitchell, 369 F.2d 323 (2d Cir. 1966), cert. denied, 386 U.S. 972 (1967) (dicta).

68 Weber v. Clifford, 289 F. Supp. 960 (D. Md. 1968).

69 McAbee v. Martinez, 291 F. Supp. 77 (D. Md.), injunctive relief denied, 393 U.S. 904 (1968).

70 In re Kelly, 401 F.2d 211 (5th Cir. 1968); Levy v. McNamara, Civil No. 953-67 (D.D.C.), aff'd sub nom. Levy v. Corcoran, 389 F.2d 929 (D.C. Cir.) (Bazelon, J., dissenting), stay denied, 387 U.S. 915, cert. denied, 389 U.S. 960 (1967); Gorko v. Commanding Officer, 314 F.2d 858 (10th Cir. 1963); cf. Stolte v. United States, Misc. No. 68-4 (U.S.M.C.A. 1968) (unsuccessful attempt to enjoin court-martial in Court of Military Appeals). But see Crane v. Hedrick, 284 F. Supp. 250 (N.D. Cal. 1968).

71 See, e.g., Brown v. McNamara, 390 U.S. 1005 (1968), and Noyd v. McNamara, 389 U.S. 1022 (1967) (attacks on denials of conscientious objector discharges and the statutory scheme); Mora v. McNamara, 389 U.S. 934 (1966), Luftig v. McNamara, 387 U.S. 945 (1967), and Mitchell v. United States, 386 U.S. 972 (1967) (attacking legality of the war in Vietnam); Morse v. Boswell, 89 S. Ct. 687 (1969), McArthur v. Chifford, 393 U.S. 1002 (1968), and Winters v. Umited States, 393 U.S. 896 (1968) (attacking activation of reserve units and individual reservists).

72 See, e.g., Chavez v. Fergusson, 266 F. Supp. 879 (N.D. Cal. 1967), appeal dismissed, 395 F.2d 215 (9th Cir. 1968) (appeal moot where petitioner had already served sentence and been discharged). 
to justify in certain cases, particularly those claiming denials of constitutional rights in courts-martial, discharges, and other administrative decisions, or indicating clear abuses of statutory authority. Other courts have rejected the strict nonreviewability doctrine but, after reviewing a case on the merits and sometimes raising a number of considerations relating to the appropriateness of court interference, have refused the requested relief. ${ }^{73}$ Still another approach has been to deny jurisdiction, not on the grounds of nonreviewability, but on the grounds that the petitioner had not exhausted available military remedies and therefore the case was not yet ripe for review by a federal court. ${ }^{74}$ This use, or perhaps abuse, of the concept of exhaustion of remedies and its relationship to the nonreviewability doctrine will be examined in the following sections.

\section{The Exhaustion of Remedies Doctrine and Jurisdiction to Review Military Determinations}

The rule that a party must exhaust the remedies available to him within the military before he can seek federal court review of a military determination has its roots both in common law and administrative law. The exhaustion concept developed as a practical requirement of finality to be met before an appellate court could review the determinations of a lower court. ${ }^{75}$ The concept also played a role in the allocation of jurisdiction between law and equity by requiring the exhaustion of legal remedies before equity would take jurisdiction. ${ }^{76}$ In administrative law the concept took on inportance in relation to court review of administrative determinations; in refusing review of such determinations, courts have been especially concerned with preserving the autonomy of administrative agencies. ${ }^{77}$ This con-

73 Stanford v. United States, 399 F.2d 693 (9th Cir. 1968) (denial of application to have record reflect disabilities suffered in military held not arbitrary or capricious or unsupported by substantial evidence); Schultz v. Clifford, 1 SSLR 3256 (D. Minn. Oct. 22, 1968) (activation of individual held proper); In re Kanewske, $260 \mathrm{~F}$. Supp. 521 (N.D. Cal. 1966) (adequate evidence in record to support denial of conscientious objector discharge), appeal dismissed sub nom. Kanewske $\nabla$. Nitze, 383 F.2d 388 (9th Cir. 1967) (habeas corpus not available after sentence served and petitioner discliarged).

74 Brown v. McNamara, 387 F.2d 150 (3d Cir. 1967), cert. denied, 390 U.S. 1005 (1968), aff'g 263 F. Supp. 686 (D.N.J. 1967); Noyd v. McNamara, 378 F.2d 538 (10th Cir.), cert. denied, 389 U.S. 1022, aff'g 267 F. Supp. 701 (D. Colo. 1967).

75 See Jaffe, supra note 28 , at 327-29.

76 See generally 2 J. Moore, Federal Practice 12.03 (2d ed. 1967).

77 Under the Anglo-American conception, administrative agencies are distinct entities; they are not a part of the judicial system. Judicial control comes in from 
cern is particularly relevant to the military which has a long tradition of independence as to its courts and administrative decisions.

The rationale behind the exhaustion of remedies doctrine includes both practical considerations of efficiency and orderly procedure, and a concern for retaining separation of powers between the judiciary and the other branches of the government. In relation to court review of military determinations, the exhaustion doctrine embodies many of the same objectives as the precept of nonreviewability. By postponing civil court review of a military determination until the military has had an opportunity to apply its expertise, exhaustion, hike nonreviewability, prevents unnecessary civilian interference in military matters and ensures military autonony over its own business.

Although there are similar justifications for the use of nonreviewability and exhaustion of remedies, there is a distinct and important difference between the two concepts. The nonreviewability doctrine is a coniplete bar to a court's jurisdiction. If the principles of the concept apply to a given case, the court has no power to review the proceedings of a military tribunal, even in determining the scope of nonreviewability in the particular case. ${ }^{78}$ Exhaustion of remedies, however, is a discretionary doctrine applied by courts to ensure that review is not premature. Although it also nuasks important interests in preserving separation of powers, this interest is served by the court's voluntarily abstention until an appropriate time, rather than by barring jurisdiction. Thus, to the extent that some recent cases intermingle the exhaustion doctrine with language from cases turning on nonreviewability, ${ }^{79}$ they would appear to be misapplying the exhaustion rule.

The exhaustion of remedies doctrine, as it has developed in adminis-

the outside. The agency is either within the Executive or, under Humpbrey's Executor, "independent." The Judiciary will not hightly interfere with a job given to the Executive until it is clear that the Executive has exceeded its mandate. The exhaustion doctrine is, therefore, an expression of executive and administrative autonomy. And it has peculiar pertinence when, as is so often the case, the agency lias been given large discretionary powers and the potential exercise of these powers is relevant to the solution of the issues for which early review is sought.

Jaffe, supra note 28 , at 328 .

78 However, several recent decisions suggest that review may be necessary in order to make an adequate determination as to the question of reviewability. See, e.g., United States ex rel. Schonbrun v. Commanding Officer, 403 F.2d 371 (2d Cir. 1968), reconsideration of denial of stay denied, 89 S. Ct. 609 (1969) (Douglas, J., dissenting); Fox v. Brown, 402 F.2d 837 (2d Cir.), aff'g 286 F. Supp. 855 (S.D.N.Y. 1968): Robson v. United States, 279 F. Supp. 631 (E.D. Pa. 1968).

79 For a discussion of this phenomenon, see text at notes 141-157 infra. 
trative law, has a number of limitations. First, one need only exhaust remedies which provide a genuine opportunity for relief. ${ }^{\text {so }}$ Second, exhaustion is not required where the petitioner may suffer irreparable injury if compelled to pursue his administrative remedies. ${ }^{81}$ Third, exhaustion is not required, under some precedents, ${ }^{82}$ if the plaintiff lias raised a substantial constitutional question. ${ }^{83}$ This is especially true when the administrative tribunal lacks the expertise or authority to resolve adequately the constitutional question. Thus, in Wills $v$. United States, ${ }^{84}$ the Ninth Circuit held that a plaintiff attacking his punitive reclassification as a violation of first amendment rights was not required to exhaust his selective service remedies:

In the first place, appellant's objection to his classification was not addressed to the area of administrative judgment. It did not pose a question upon which courts, bowing to special expertise, would regard the administrative determination as final, save only where basis in fact is lacking. His objection, founded upon a claim of constitutional right, was one on which courts have little reason to defer to administrative determination. The exhaustion rule loses much of its force in this area. ${ }^{85}$

These limitations on the exhaustion doctrine are, of course, only working guides which courts have devised for dealing with administrative agencies. The degree to which the military can be analogized to an administrative agency or a state court system in its relation to the federal courts has been subjected to little judicial scrutiny. While certain historical and constitutional differences between the military and these other semi-autonomous systems indicate that wholesale application of administrative law exhaustion principles to the military may be inappropriate, there are distinct similarities between the systems, and as the traditional concept of absolute military immunity from civil court interference continues to wane, the principles of exhaustion nuust

80 See Jaffee, supra note 28 , at 329.

81 Eccles v. People's Bank, 333 U.S. 426, 434 (1948); Oklahoma Natural Gas Co. v. Russell, 261 U.S. 290 (1923); Colonial House, Inc. v. Connecticut St. Bd. of Lab. Rel., 23 Conn. Supp. 30, 176 A.2d 381 (Super. Ct. 1961).

82 Utah Fuel Co. v. National Bituminous Coal Comm'n, 306 U.S. 56 (1939); Isbrandtsen v. United States, 211 F.2d 51 (D.C. Cir. 1954); see Jaffee, supra note 28, at 331-34.

83 See 3 K. Davis, Administrative Law Treatise $\$ 20.04$ (1958).

84384 F.2d 943 (9th Cir. 1967).

85 Id. at 945 . 
have considerable weight in determining the timeliness of civilian court review of military determinations.

There is a basic similarity between state and military courts in their relationship to the federal courts: Untimely federal court interference is a threat to the autonomy of both. Exhaustion of remedies was introduced into state-federal relations when Congress extended habeas corpus jurisdiction over state prisoners to the federal courts in $1867,{ }^{86}$ and in $E x$ parte Royall ${ }^{\$ 7}$ it was interpreted as an aspect of comity required to maintain the proper state-federal balance. ${ }^{88}$ Since the scope of habeas corpus review of military determinations orginally extended only to the question of whether the military tribunal had proper jurisdiction, ${ }^{89}$ there was little need at that time for a rule of military exhaustion to deal with premature review. While a few early decisions seemed to rely upon considerations peculiar to the exhaustion doctrine, ${ }^{90}$ explicit reliance upon the concept was not often utilized until after World War II when the expanded scope of habeas corpus review of military determinations raised the spectre of federal courts being inundated by the habeas corpus applications of military personnel. ${ }^{91}$

In 1949, Article of War 53,92 (now Article 73 of the Uniform Code

86 Act of February 5, 1867, ch. 28, $\$ 1,14$ Stat. 385 .

87117 U.S. 241 (1886).

88 Regarding the scope of habeas corpus review of state courts, see generally $\mathrm{C}$. Wright, Federal Courts 177-86 (1963). With respect to federal courts see W. Aycock \& S. Wurfer, supra note 30 , at 314-78.

89 See text at note 30 supra.

90 E.g., Wales v. Whitney, 114 U.S. 564 (1885), in which the Supreme Court held that it had no habeas corpus jurisdiction to determine the validity of military orders and that the petitioners could raise the question of their legality in the military courts.

91 See W. AYcock \& S. WuRfer, supra note 30, at 314, 350-54.

92 Article 53 conferred discretionary authority upon the Judge Advocate General to grant a new trial, vacate a sentence, or modify a discharge if application for such rehef was made within one year after final determination of the case upon initial military appellate review. The Article ended with the following proviso:

Provided ... That all action by the Judge Advocate General pursuant to this article ... shall be final and conclusive ... and all action taken pursuant to such proceedings, shall be binding upon all departments, courts, agencies, and officers of the United States.

Manual for Courts-Martiat, Untred States Army 291 (1949), 13 Fed. Reg. 7519, 7550 (1949). Whelchel v. McDonald, 178 F.2d 760 (5th Cir. 1949), aff'd, 340 U.S. 122 (1950), stated that "the last words of the amended Article of War 53, seem to make the action of the Judge Advocate General refusing a new trial binding upon the courts of the United States." However, Schilder v. Gusik, 180 F.2d 662 (6th Cir. 1950), rev'd on otber grounds, 340 U.S. 128 (1950), read the same words (which are now part of Art. 76, UCMJ) as giving the Judge Advocate General's determination, under Art. 53, finality upon the merits only and not as precluding habeas corpus attack. United 
of Military Justice ${ }^{93}$ ) was passed by Congress to permit, under certain conditions, a petition for new trial within one year after approval of a court-martial sentence by the convening authority. In 1951, a new Manual for Courts-Martial was published and included the following provision:

Prior to the exhaustion of the remedies of appellate review and petition for new trial which are available to an accused person, . . . a resort to habeas corpus to test the legality of restraint imposed pursuant to a sentence of a court-martial is inappropriate and premature. ${ }^{94}$

Commentators have observed that these changes were intended to establish adequate post-conviction procedures within the military which must be exhausted as a prerequisite to federal habeas corpus review. ${ }^{95}$

One year later, a case concerning the scope and application of Article 53 in relation to the exhaustion of remedies requirement reached the Supreme Court. In Gusik v. Schilder, ${ }^{96}$ a petitioner convicted of murder by a court-martial petitioned for a writ of habeas corpus on the ground that the court-martial lacked jurisdiction due to denial of statutory and constitutional rights to a pre-trial investigation and effec-

States v. Augenblick, 89 S. Ct. 528, 530 (1969) (dicta), states that habeas corpus relief is an "implied exception" to Art. 76, UCMJ.

93 Article 73 reads:

Petition for a new trial. At any time within one year after approval by the convening authority of a court-martial sentence which extends to death, dismissal, dishonorable or bad-conduct discharge, or confinement for one year or more, the accused may petition the Judge Advocate General for a new trial on the ground of newly discovered evidence or fraud on the court.

Manual for Courts-Martial, Untted States (1951). Article 73 was amended in 1968 to extend the time for appeal from one to two years and to permit the accused to petition for a new trial in all cases where there is newly discovered evidence or fraud on the court. The Military Justice Act of 1968, Pub. L. No. 90-632, $\$ 873$ art. 73 (Oct. 24, 1968), I U.S. Code CoNG. \&. Ad. News 1570-71 (1968).

94 Manual for Courts-Martial, United States $1214 \mathrm{~b}$. at 389 (1951). The chapter concerning exhaustion and habeas corpus within the military has been deleted from the 1969 edition of the MANUAL.

95 It is important to remember the extraordinary nature of habeas corpus, the basic doctrine of the necessity of full exhaustion of all other remedies first, the vast administrative burden that abusive resort to the writ has cast upon the courts and the desire of both the courts and Congress to establish post-conviction hearing procedures which are both more adequate and more conclusive than the traditional writ of habeas corpus ad subjiciendum . . . A Article of War 53, and its Uniform Code successor, Article 73, constitute the congressional solution to the problem in military cases just as section 2255 is its solution to the problem in civil cases.

W. AycocK \& S. WuRFEI, supra note 30, at 344.

96340 U.S. 128 (1950). 
tive assistance of counsel. Analogizing the situation to state-federal habeas corpus practice, the Court stated that the reason for requiring exhaustion is that interference by the federal court may be a needless cause of friction if the military does offer a remedy, ${ }^{97}$ and ruled that the district court should refuse to hear the case pending petitioner's exhaustion of his remedy under Article 53.

The exhaustion of remedies doctrine was codified at approximately the same time in the state-federal ${ }^{9 s}$ and the military-federal contexts. Since that time, however, the exhaustion requirement as applied to federal court review of state decisions has been significantly liberalized. In Fay v. Noia, ${ }^{99}$ the Supreme Court materially reduced the exhaustion requirement by holding that a state prisoner who failed to appeal his conviction in time can nevertheless obtain federal habeas corpus review because the section 2254 exhaustion requirement ${ }^{100}$ only applies to state remedies available at the time of application for habeas corpus. ${ }^{101}$ No analogous development has taken place regarding federal habeas corpus jurisdiction over court-martial convictions. This can be explained in part, perhaps, by the fact that the Court of Military Appeals has taken an active role in upholding and extending due process rights in courtsmartial, ${ }^{102}$ thus lessening the need to liberalize the exhaustion rule. That liberalization of court review which has occurred has tended to concern the fact and scope of review, rather than the exhaustion element of timing.

The development of the exhaustion doctrine regarding court review

$97 \mathrm{ld}$. at 132.

9828 U.S.C. $\$ 2254$ (1964) (originally enacted as Act of June 25, 1948, ch. 646, 62 Stat. 967).

99372 U.S. 391 (1963).

100 See note 98 supra.

101 See also Townsend v. Sain, 372 U.S. 293 (1963), providing guidelines as to when a hearing must be granted by federal courts on liabeas corpus applications.

102 The Court of Military Appeals has extended to servicemen such due process rights as the right to a speedy trial, United States v. Schlack, 14 U.S.C.M.A. 371, 34 C.M.R. 151 (1964); right to confront witnesses, United States v. Jacoby, 11 U.S.C.M.A. +28, 29 C.M.R. 244 (1960); right of protection against unreasonable searches and seizures, United States v. Vierra, 14 U.S.C.M.A. 48, 33 C.M.R. 260 (1963); United States v. Nowling, 9 U.S.C.M.A. 100, 25 C.M.R. 362 (1958); privilege against self-incrimination, United States v. Kemp, 13 U.S.C.M.A. 89, 32 C.M.R. 89 (1962); right to a public trial, United States v. Brown, 7 U.S.C.M.A. 251, 22 C.M.R. 41 (1956); right to compulsory process, United States v. Sweeney, 14 U.S.C.M.A. 599, 34 C.M.R. 379 (1964); and the right to pre-interogation warnings, United States v. Tempia, 16 U.S.C.M.A. 629, 37 C.M.R. 249 (1967). See generally Quinn, The United States Court of Military Appeals and Military Due Process, 35 St. JoHN's L. Rev. 225 (1961). 
of military administrative determinations has paralleled that concerning court-martial decisions. Where military regulations have made various channels of appeal or remedies available, courts have uniformly required that these channels be exhausted before seeking court review. The question often arises, however, as to whether a particular forum or channel is indeed necessary to achieve finality and whether it actually provides a genuine source of relief. For example, the discharge cases have created a dispute over whether one must exhaust all the military administrative boards created for post-discharge review before seeking court review. ${ }^{103}$ Clearly, seeking court review before discharge is final would be a failure to exhaust administrative remedies. Thus, in Bernstein $v$. Herren, ${ }^{104}$ two soldiers were refused declaratory judgment relief from a threatened administrative discharge because the discharge proceedings had not yet gone beyond a Field Board of Inquiry, and therefore the injury might never materialize. ${ }^{105}$

More difficult problems arise when an individual has already been discliarged from the service, and there is a split among the circuit courts as to whether boards for correction of records and discharge review must always be petitioned unsuccessfully before resort can be made to the federal courts. The Fifth Circuit in McCurdy v. Zuckertos has held that the district courts lack jurisdiction in the absence of exhaustion of post-discharge review boards because such boards offer "complete retroactive restoration." However, the D.C. Circuit in Ogden

103 Discharge review boards are established by each service pursuant to 10 U.S.C. $\$ 1553$ (1964). They are composed of military officers, follow a relatively informal procedure and will grant a hearing automatically upon request for review of any discharge or dismissal to determine whether an error or injustice has been made. Boards for the correction of records are established by each service under 10 U.S.C. $\$ 1552$ (1964). They are composed of civilians serving part time and do not grant hearings to an applicant as a matter of right. Subject to approval by the Secretary of the military department involved, they can grant change of type of discharge, ehimination of discharge and restoration to duty, restoration to rank, or elimination of derogatory information from applicant's military records. See Joint Hearings on S. 745-62, S. 2906-7, Before the Subcomm. on Constitutional Rights of the Senate Comm. on the Judiciary, 89th Cong., 2d Sess., pt. 3, at 828-33 (1966); Everett, Military Administrative Discharges -The Pendulum Swings, 1966 Duke L.J. 41; Meador, Judicial Determinations of Military Status, 72 YaLE L.J. 1293 (1963).

104141 F. Supp. 78 (S.D.N.Y. 1956).

105 Similarly, in Michaelson v. Herren, 242 F.2d 693 (2d Cir. 1957), a sergeant was denied injunctive relief to prevent an admimistrative discharge because he had neither been discharged nor petitioned the discharge review boards.

106359 F.2d 491 (5th Cir. 1966), cert. denied sub nom. McCurdy v. Brown, 385 U.S. 903; accord, Tuggle v. Brown, 362 F.2d 801 (5th Cir. 1966) (per curiam). 
v. Zuckert ${ }^{107}$ permitted an Air Force officer to obtain court review of his medical disability discharge even though he had not petitioned the Air Force Board for Correction of Military Records. The court found that the statute which established the Board ${ }^{108}$ was not intended to affect judicial jurisdiction, but to relieve Congress of having to pass private legislation aimed at remedying individual discharges. The extent of the court's actual reliance on this legislative intent is unclear, for the court went on to emphasize that a determination from the Board may take up to three years and that even if the Board finds in petitioner's favor, the power to correct the discharge is not in the Board but in the Secretary of the Air Force who is only bound to make corrections "when lie considers it necessary." 109 These factors demonstrate the court's concern with the adequacy of the available relief rather than the legislative intent. Furthermore, the court stressed the fact that the principle of exhaustion is discretionary $y^{110}$ and tempered its decision by stating that on remand the district court could, in its discretion, reject jurisdiction pending application for relief from the military board. Thus, although Ogden raised serious questions as to whether correction of records boards are intended as a step in the finality of a discharge determination and whether they provide an adequate remedy, it left the weighing of such considerations to the lower court's discretion. Subsequent circuit court opinions have followed this discretionary approach. ${ }^{111}$

The considerations to be weighed by the court in applying its discretion witl regard to exhaustion include the adequacy of the military remedy, the threat of irreparable injury, and the existence of substantial constitutional questions. Indeed, it is the treatment of these considerations whicl distinguishes between a strict and a liberal apphication of the exliaustion doctrine. One of the few Supreme Court cases concerning the doctrine in military discharge cases provides a somewhat stringent application. In Beard v. Stabr, ${ }^{112}$ an Army lieutenant colonel sought to enjoin the Secretary of the Army from giving him a general

\footnotetext{
107298 F.2d 312 (D.C. Cir. 1961).

10810 U.S.C. $\$ 1552$ (a) (1964).

109298 F.2d at 316-17.

110 Id. at 317.

111 Nelson v. Miller, 373 F.2d 474 (3rd Cir.), cert. denied, 387 U.S. 924 (1967); Sohm r. Fowler, 365 F.2d 915 (D.C. Cir. 1966). Sobm held that when post-discharge remedies have not been exhausted, the district court should retain jurisdiction but defer decision unless there are "special circumstances."

112370 U.S. 41 (1962) (per curiam).
} 
discharge for conduct unbecoming an officer. The suit was brought after the Army Board of Review recommended discharge but before the Secretary had made his decision, and alleged that the Board's proceedings denied the officer due process of the law. The Supreme Court, in a per curiam opinion with five justices joining, directed that the suit be dismissed for prematurity since the Secretary had not yet exercised his discretionary authority and because the appellant had adequate procedures for seeking redress if he were removed from the active hist. ${ }^{113}$

Justice Douglas, joined by Justice Black, dissented on the grounds that the hearing had denied petitioner due process by putting the burden of proving fitness on him and denying confrontation with his accuser. The dissent maintained that the suit was ripe for adjudication because even if the Secretary's decision were favorable, and even if petitioner could recover loss of salary and pension in a subsequent collateral action, the proceeding involved the considerable issues of a man's professional standing, character, and claim to an honorable discharge. ${ }^{114}$ Justice Douglas focused obliquely on the irreparable injury and constitutional question aspects of the exhaustion principle by arguing that a petitioner should not have to wait to attack an obviously unconsitutional administrative proceeding until the Secretary had determined to remove him from the active list. Such continued delay, the argument suggests, causes irreparable injury to reputation which cannot be repaired even by a final favorable determination. Thus Beard, unlike Ogden which concentrated on the adequacy of remedy, was primarily concerned with whether the exhaustion requirement should be waived in light of threatened irreparable injury. The fact that the majority supported exhaustion despite fairly persuasive evidence of at least intangible injury indicates a particular interest in requiring "finahty" in military discharge determinations which may not easily be overridden by claims of irreparable injury.

Thus, prior to the Vietnam War period, the exhaustion of remedies doctrine apphicable to military determinations had still not been thoroughly investigated and explained in the courts. The few relevant decisions were more expressions of judicial attitudes than clear, analytical statements of principles and guidelines to be employed in applying the doctrine. With the advent of the Vietnam War, however, the judiciary was given a greater opportunity to dissect the exhaustion 
principle, due largely to the magnification of problems attending the administration of conscientious objector discharges.

\section{Application of the Exhaustion Doctrine to Conscientious Objector Discharge Cases During the VIETNAM WAR}

Throughout the last fifty years, discharge cases have accounted for the majority of suits seeking court review of military determinations. The bases for such suits have often reflected problems and conflicts peculiar to the times in which they were brought. For example, discharge suits between the two world wars were largely brought by career officers seeking to prevent their separation under manpower reduction programs; ${ }^{115}$ suits during World War 11 , the Korean War, the Vietnam War, and other periods of increased conscription predominantly sought to force the military to grant a discharge; ${ }^{116}$ and many of the suits brought between the Korean and Vietnam Wars sought to upgrade a less than honorable discharge awarded because of allegedly subversive, homosexual, or other unacceptable conduct. ${ }^{117}$ A distinctive genus of suit during the Vietnam War has been that concerned with the conscientious objector discharge. The suit was only made possible by a 1962 change in military regulations which provided for discharge of conscientious objectors whose views developed or crystallized after induction. ${ }^{118}$ While the United States had always provided for some form of exemption from the draft for conscientious objectors, ${ }^{119}$ this

115 See, e.g., United States ex rel. French v. Weeks, 259 U.S. 326 (1922); United States ex rel. Creary v. Weeks, 259 U.S. 336 (1922).

${ }^{116}$ See, e.g., Nelson v. Peckham, 210 F.2d 574 (4th Cir. 1954), and cases cited notes $6,7,8,32$ supra.

117 See, e.g., cases cited notes $53,55,60,62$ supra.

118 Department of Defense (DOD) Directive No. 1200.6 (Aug. 21, 1962) was issued by the Secretary of Defense pursuant to his power over the Department of Defense in 10 U.S.C. $\$ 133$ (1964). Its purpose was stated as providing "uniform procedures for the utilization of conscientious objectors in the Armed Forces and consideration of requests for discharge on the grounds of conscientious objection." It has been replaced by DOD Directive No. 1300.6 (May 10, 1968) which made two changes: First, claims "based on conscientious objection growing out of experiences prior to entering military service, but which did not become fixed until entry into the service, will [now] be considered," $i d$. at 3 , while previously objection had to develop before entry; second, there is now an opportunity to appear "before an officer in the grade of O-3 or higher, who is knowledgeable in policies and procedures relating to conscientious objector matters" who "will enter his recommendation and the reasons therefor into the file." Id. at 7.

119 See Mansfield, Conscientious Objection-1964 Term, in 3 Ret.utox aNd the Ptbu. Order 1 (1965). 
was the first time that provision was made for discharge of in-service conscientious objectors. Since the new administrative scheme was established by a Department of Defense directive ${ }^{120}$ and implementing service regulations, ${ }^{121}$ it seems logical to expect that admimistrative law considerations would be important in determining the extent to which the courts should grant review of the military determinations.

The administrative scheme established in the service regulations provides that a serviceman seeking a conscientious objector discharge or noncombatant status must submit an application in writing to his immediate commanding officer, providing answers to detailed questions concerning his behefs and attaching supporting documents and letters. The commanding officer is required to talk to the applicant personally, and to arrange for an interview with a chaplain and a military psychiatrist. Under a recently added provision in the Department of Defense directive ${ }^{122}$ an applicant may request an opportunity to appear in person before an officer in the grade of O-3 (captain in the Army and Air Force, lieutenant in the Navy) or higher, and that the officer will record his recommendations and reasons therefor. The reports of these interviews, together with the recommendation of the commanding officer, are forwarded to the appropriate departmental headquarters official, the Army Adjutant General, the Chief of Naval Personnel or the Secretary of the Air Force. At this stage the file is referred to the National Director of Selective Service for an advisory opimion as to whether the individual would qualify for conscientious objector status under the Selective Service laws. Although this opinion is not binding, the departmental headquarters official frequently follows it. ${ }^{123}$

120 See note 118 supra.

121 See Army Reg. 635-20 (Dec. 3, 1968); Air Force Reg. 35-14; Bureau of Naval Personnel Instruction 1616.6.

122 See note 118 supra.

123 DOD [Directive] $1300.6 \ldots$ provides that "claims of conscientious objection by all persons, whether existing before or after entering military service should be judged by the same standards." Accordingly, [the headquarters official referred the application for conscientious objector status] to the Director of the Selective Service System, General Hershey, for an "advisory opinion" of its validity; the regulations contemplate that a negative decision by General Hershey will normally be decisive.

Hammond v. Lenfest, 398 F.2d 705, 709 (2d Cir. 1968). The charge has been made that the Selective Service had been advising the armed services "to deny applications for discharge on the grounds of conscientious objection ... for the purpose of discouraging sucl in-service applications." Petitioner's Brief for Habeas Corpus at 3, Mandel v. Dayton, Civil No. 68-2695 (S.D.N.Y. Sept. 3, 1968) (judgment ordering Coast Guard to discharge petitioner as conscientious objector). 
Once the official makes his final decision, the applicant must receive written notice of the decision together with reasons for any denial of discharge.

While the directive declares that it does not create a vested right in an individual to be either processed or granted a discharge, ${ }^{124}$ there is judicial support for the contention that there are certain constitutional rights (arising out of either the first amendment or the due process clause of the fifth amendment) upon which a valid claim for court review of a denial of discharge can be based. ${ }^{125}$ The nature of such a claim and the grounds for attacking a denial of discharge have been previously suggested:

Obviously, the serviceman whose request for discharge has been denied cannot petition the court for relief, alleging simply that the denial was unjust; he must also specify the manner in which it was unjust. From the practical standpoint, he can accomplish this only through the use of one or more of three basic approaches: 1) an attack on the final decision, as having been unreasonably, arbitrarily, or discriminatorily made; 2) an attack on the procedural scheme which the regulations establish, either as lacking the minimum essentials of constitutional due process or as fostering the denial of equal protection of the laws; 3) an attack on the procedure actually followed in the particular case, as involving an unlawful departure from the administrative scheme. ${ }^{126}$

Suits have been based on all three of these approaches. However, broad attacks upon the procedural scheme have not been successful, ${ }^{127}$ and frequently there is no procedural flaw in the processing of an individual's claim. Thus, suits for review have increasingly been based on assertions that the denial was arbitrary because it had "no basis in fact." The "no basis in fact" test, developed in Selective Service determination review cases, ${ }^{128}$ appears to have been accepted by the

124 DOD Directive No. 1300.6 at 2 (May 10, 1968).

125 See Comment, God, The Amy, and Judicial Review: The In-Service Conscientious Objector, 56 CALIF. L. Rev. 379, 397-404 (1968). See also Macgill, Selective Conscientious Objection: Divine Will and Legislative Grace, 54 VA. L. REv. 1355 (1968).

126 God, The Arny, and Judicial Review, supra note 125, at 404-05.

127 See, e.g., Brown v. McNamara, 387 F.2d 150 (3d Cir. 1967), cert. denied, 390 U.S. 1005 (1968), aff'g 263 F. Supp. 686 (D.N.J. 1967); Noyd v. McNamara, 378 F.2d 538 (10th Cir.), cert. denied, 389 U.S. 1022, aff'g 267 F. Supp. 701 (D. Colo. 1967).

128 See Dickinson v. United States, 346 U.S. 389 (1953); Estep v. United States, 327 U.S. 114 (1946). The test was codified in 50 U.S.C. app. $\S 460(\mathrm{~b})(3)(1964)$, as amended, 50 U.S.C.A. app. $\$ 460$ (b) (3) (1968). 
courts in determining whether substantive due process has been accorded by a military body which considers a petition for a conscientious objector discharge. ${ }^{129}$

With the first flood of conscientious objector cases prompted by the Vietnam War draft, federal courts, having little experience in this area, tended to accept jurisdiction but then rule against the petitioner on the merits. ${ }^{130}$ This pattern, however, was quickly arrested by two circuit court decisions. Both Noyd v. McNamara ${ }^{131}$ and Brown v. $M c N a m a r a^{132}$ refused to grant review to servicemen seeking conscientious objector discharges and Noyd established a strict rule of exhaustion to support its decision, apparently presaging the continued foreclosure of federal court review in conscientious objector cases ${ }^{\mathbf{1 3 3}}$ and perhaps other military determinations.

In June 1968, the Second Circuit refused to follow the lead of Noyd and Brown and in Hammond v. Lenfest ${ }^{134}$ allowed review of the claim of an in-service conscientious objector despite his failure to exhaust the available military remedies. With two other circuits subsequently

129 See Hammond v. Lenfest, 398 F.2d 705, 716 (2d Cir. 1968); deRozario v. Commanding Officer, 390 F.2d 532 (9th Cir. 1967); Crane v. Hedrick, 284 F. Supp. 250 (N.D. Cal. 1968). But see Brown v. McNamara, 387 F.2d 150, 152-53 (3d Cir. 1967), cert. denied, 390 U.S. 1005 (1968), aff'g 263 F. Supp. 686 (D.N.J. 1967), declining to pass on whether "no basis in fact" is the appropriate test for review. Although the "no basis in fact" test has been described as tlie "narrowest known to the law," Blalock v. United States, 247 F.2d 615, 619 (4th Cir. 1957), it has been applied liberally in Selective Service cases. See Kessler v. United States, 406 F.2d 151 (5th Cir. 1969); Lewis v. Secretary, 402 F.2d 813 (9th Cir. 1968); Batterton v. United States, 260 F.2d 233 (8th Cir. 1958); United States v. St. Clair, 293 F. Supp. 337 (E.D.N.Y. 1968). The test may be required for review of conscientious objector discliarges in order to conform to the scope of review granted to Selective Service conscientious objector determinations. However, a broader test, sucli as "substantial evidence," may be appropriate for review of other military administrative determinations. See, e.g., Sanford v. United States, 399 F.2d 693 (9th Cir. 1968) (finding determination of Army Board for Correction of Military Records not arbitrary, capricious, or unsupported by substantial evidence).

130 See, e.g., In re Kanewske, 260 F. Supp. 521 (N.D. Cal. 1966), appeal dismissed sub nom. Kanewske v. Nitze, 383 F.2d 388 (9th Cir. 1967); Gilliam v. Reaves, 263 F. Supp. 378 (W.D. La. 1966).

131378 F.2d 538 (10th Cir. 1967).

132387 F.2d 150 (3d Cir. 1967).

133 Capt. Noyd, for example, has still not exhausted his military reniedies (which would allow him to obtain a review on the merits) although two years have passed since his suit in the United States District Court for injunctive relief was denied on the grounds of failure to exhaust remedies. See text at notes 177-81 infra.

134398 F.2d 705 (2d Cir. 1968). 
reaching the same result as Hammond ${ }^{135}$ and the Supreme Court's denial of certiorari in both Noyd ${ }^{136}$ and Brown, ${ }^{137}$ there is a temporarily irreconcilable split among the circuits. While the issue may be avoided if the military continues its recent trend towards allowing conscientious objector discharges ${ }^{138}$ and broadens the defenses of conscientious objectors in military courts-martial, ${ }^{139}$ such a result is indeed unlikely. The resolution therefore, will probably have to come from the courts. If the courts continue to follow Hammond by hearing cases on the merits, the Noyd doctrine may eventually be rejected as an overly strict reaction to sensitive political issues; such a development would open the way for increased review of military determinations in nunierous areas. In order to determine if indeed the courts will take this approach in the future, a detailed look must first be taken at Noyd, Brown and Hammond.

\section{Noyd v. McNamara}

Captain Dale Noyd became an Air Force officer in 1955, pursued graduate studies in psychology at the University of Michigan for three years from 1960 to 1963 under an Air Force education program, and was then assigned as an Assistant Professor of Psychology at the United States Air Force Academy. On December 8, 1966, he submitted a letter of resignation to the Secretary of the Air Force, stating that he was "opposed to the war that this country is waging in Vietnam" ${ }^{400}$ and in subsequent letters requested that he be reassigned to duties providing minimum conflict with his beliefs or, alternatively, that he be discharged as a conscientious objector. All his requests were denied and he eventually received orders assigning him to fighter pilot training, creating the probability that he would thereafter be sent to Vietnanr. He thereupon filed a suit in federal court seeking declara-

135 In re Kelly, 401 F.2d 211 (5th Cir. 1968); Bates v. Commanding Officer, Misc. Civil No. 68-64-F (D. Mass. Oct. 29, 1968), rev'd, No. 7241 (1st Cir. Jan. 7, 1969).

136389 U.S. 1022 (1967).

137390 U.S. 1005 (1968).

$138 \mathrm{See}$, e.g., consent order for discharge entered by Coast Guard in Mandel v. Dayton, Civil No. 68-2695 (S.D.N.Y. Sept. 3, 1968), described in N.Y. Times, Sept. 4, 1968 , at 14 , col. 4 .

130 For a case which may result in a more liberal approach to conscientious objectors within the military, see United States v. Noyd, A.C.M. 20,121 (Sept. 3, 1968), appeal docketed, No. 21,642, U.S.C.M.A. Jan. 23, 1969. See notes 225-26 infra and accompanying text.

${ }_{140}$ Noyd v. McNamara, 267 F. Supp. 701, 703 (D. Colo.), aff'd, 378 F.2d 538 (10th Cir.), cert. denied, 389 U.S. 1022 (1967). 
tory relief, an injunction, and writs of habeas corpus and mandamus to require the Air Force either to assign him to duties consistent with his beliefs or to dismiss him. His alleged bases for relief were first, that his application was improperly and discriminatorily denied in violation of his rights under the Constitution, statutes and regulations; second, that the pertinent Air Force regulation lacked minimum criteria of procedural due process; and third, that the Air Force had failed to give reasons for disapproval of his application as required in its own regulation.

The district court ${ }^{141}$ concluded that it had no jurisdiction to entertain the suit because Noyd had not yet been court-martialed for refusing to obey orders and appealed any conviction through all military appeal channels. The court mingled the policy reasons for the exhaustion rule freely with the reasons for a general policy of nonreviewability:

There is good reason for the strict requirement of exhaustion as a prerequisite to jurisdiction. In part it is based on the separation of powers and particularly the desirability of allowing the military to govern its own affairs without interference from the courts. If courts were allowed to entertain these suits at any stage of the military proceedings, the delays incident to litigation could of themselves render military orders ineffectual. ${ }^{142}$

The court relied heavily upon the nonreviewability doctrine decisions, ${ }^{143}$ and appears to have viewed the exhaustion doctrine as just another vehicle for preventing review of military determinations. Although Noyd argned that he was only obligated to pursue the remedies provided in the procedural regnlation pertaining to conscientious objectors, the court rejected this contention with references to cases that had also confused exhaustion with nonreviewability. ${ }^{144}$ Similarly, although Noyd argued that requiring him to violate military

$141 \mathrm{ld}$. at 708.

142 Id. at 707 .

143 Id. at 706 .

144 Escherving substantive analysis, the court merely cited three district court decisions which had freely intermixed exhaustion and nonreviewability principles and indeed, had relied to a great extent on the concepts of Orloff, see text at note 63 supra. The three cases cited were: Brown v. McNamara, 263 F. Supp. 686 (D.N.J.), aff'd, 387 F.2d 150 (3d Cir. 1967), cert. denied, 390 U.S. 1005 (1968); Chevez v. Fergusson, 266 F. Supp. 879 (N.D. Cal. 1967); Petition of Green, 156 F. Supp. 174 (S.D. Cal. 1957), appeal dismissed as moot, 264 F.2d 63 (9th Cir. 1959). 
law and risk court-martial in order to secure review would unreasonably place him in jeopardy, and indeed would be futile in view of the past rejections of his claim, the court dismissed these considerations by cursory references to cases not involving administrative remedies. ${ }^{145}$ Aside from failing to delineate the policy considerations relevant in exhaustion situations, the court seemed unaware of the implications of requiring exhaustion of an entire set of military judicial remedies which had no connection with the administrative scheme governing conscientious objector discharges. In a per curiam decision, the Tenth Circuit adopted the lower court's opinion, merely adding a few words to endorse the district court's view of the exhaustion issue. ${ }^{148}$

145 In answer to Noyd's contention that a refusal to grant him relief in court "would unreasonably force him to violate military law" and that this is contrary to the theory and purpose of declaratory proceedings, $267 \mathrm{~F}$. Supp. at 706, the conrt merely stated that the cases did not support this argument and cited two cases involving the nonreviewability doctrines, Wales v. Whitney, 114 U.S. 564 (1885); Orloff v. Willoughby, 345 U.S. 83 (1953), and two decisions involving attempts to obtain court review of court-martial rather than administrative determinations, Gnsik v. Schilder 340 U.S. 128 (1950); Gorko v. Commanding Officer, 314 F.2d 858 (10th Cir. 1963).

146 Although appellant has exhausted his administrative remedies as that term is concerned with Air Force regulations, he has not exhausted the military process and has not been denied, nor can we anticipate that he will be denied, a full consideration of his constimtional rights within the complete scope of that process.

Noyd v. McNamara, 378 F.2d 538, 539-40 (10th Cir. 1967).

Noyd also offered an argument based upon Dombrowski v. Pfister, 380 U.S. 479 (1965) (upholding federal court injunction of threatened state court prosecutions under vague state statntes to prevent "chilling effect" on first amendment rights). Noyd argued that the doctrine of Dombrowski should be expanded to afford injunctive relief to assure determination of his first amendment right to religious freedom without exposure to court-martial proceedings, on the theory that if such exposnre were a prerequisite to judicial relief, other individuals with meritorious conscientious objection claims would be deterred from asserting their right to free exercise because of punishment and the absence of a ready means of redress. Petitioner's Brief for Certiorari at 23-25, Noyd v. McNamara, 389 U.S. 1022 (1967). The Second Circuit had recently found a "chilling effect" sufficient to justify federal court intervention in a Selective Service context. Wolff v. Selective Service Local Bd. No. 16, 372 F.2d 817 (2d Cir. 1967). However, the Tenth Circuit rejected the Dombrowski argument as "contrary to established law," citing only pre-Dombrowski cases. $378 \mathrm{~F} .2 \mathrm{~d}$ at 540 n.2.

Noyd's argument was limited by the fact that no court has yet extended Dombrowski to a military context, that it is yet unclear whether the right to conscientious objection status is constitutionally protected under the first amendment, see Macgill, Selective Conscientious Objection: Divine Will and Legislative Grace, 54 VA. L. REv. 1355, 1385-93 (1968); Mansfield, Conscientious Objection-1964 Term, in 1965 ReLrgion AND THE Public Order 1, 59-67, and that both Dombrowski and Wolff concerned the exercise of free speech rather than the free exercise of religion. The question of Dombrowski's application to the military has been raised unsuccessfully in the free speech context in Levy v. Corcoran, 389 F.2d 929 (D.C. Cir.), cert. denied, 389 U.S. 960 (1967), 


\section{Brown v. McNamara}

Private Brown, after enlisting in the United States Army and serving two weeks of basic training, applied for a conscientious objector discharge on the grounds that his beliefs had crystallized to the point that he was compelled to refuse to serve in the military. He complied with all the military procedures and submitted documentation of the sincerity of his claim, but the advisory opinion of the Director of Selective Service was that Brown could not be properly classified as a conscientious objector and thereafter the Adjutant General demied his application. Brown then refused to draw combat equipment and after being court-martialed, filed a petition for writ of habeas corpus, alleging: (1) that denial of his application was arbitrary and without basis in fact, thus violating the apphicable statutes and regulations and the due process clause of the fifth amendnient, and (2) that the procedures in the regulations denied him equal protection of the law because he was not given the hearing rights accorded those seeking conscientious objector status prior to entering the armed forces. The district court decision ${ }^{147}$ first disposed of the attack on the statutory and regulatory provisions by finding that they did not result in a denial of equal protection, but then found that it had no jurisdiction to review the final deternination of the Adjutant General. Relying on the nonreviewability language in Orloff, ${ }^{148}$ the court refused to address even the limited question of whether the military determination had any basis in fact. ${ }^{149}$

While the court's decision was essentially based on the doctrine of nonreviewability and it never explicitly mentioned the exhaustion principle, it nevertheless emphasized the timing aspect of the attempt to obtain court review, ${ }^{150}$ which is clearly related to the problem of

in an attempt to prevent the military from court-martialing an officer on charges arising out of activities he claimed were protected by the first amendment.

147263 F. Supp. 686 (D.N.J. 1967), aff'd, 387 F.2d 150 (3d Cir. 1967), cert. denied, 390 U.S. 1005 (1968). This decision was rendered prior to the district court decision in Noyd and was cited in that decision, 267 F. Supp. at 708.

148 See text at note 63 supra.

149263 F. Supp. at 693.

150 The Court distinguished the precedents permitting federal court review of preinduction classification by a draft board, and of the form of discharge, on the basis of their timing:

Such litigation at the beginning and end of the military term of service is not nearly as disruptive to the function of the armed services as that which threatens the very utilization of the manpower which has been assembled for active service.

Id. The court also expressed conceru lest the military become "entangled in litigation" 
exhaustion. Indeed, the district court opinion was subsequently cited by the district court in Noyd for the proposition that exhaustion of remedies is required in cases seeking review of conscientious objector determinations, ${ }^{151}$ and the circuit court noted that Brown had not yet exhausted all his military remedies. ${ }^{152}$

By the time Brown's appeal had reached the Third Circuit, the Tenth Circuit's opinion in Noyd had already been decided. The Third Circuit, with separate opinions by the three judges, affirmed the district court's denial of the writ of habeas corpus, but not on the grounds suggested by the lower court. Judge Van Dusen's leading opinion began by affirming the lower court's conclusion "that the administrative scheme set up by the Department of Defense and the Army does not of itself result in any constitutional violation." 153 While making this determination, however, the opinion specifically stated, contrary to the district court's contention, that the federal courts have power to review questions involving procedural due process, ${ }^{154}$ presumably including review of the procedure used at a specific trial. Judge Van Dusen then held that the bases for refusal in this case were neither arbitrary nor irrational. ${ }^{155}$

The decision thus appears to be explicable as a judgment that the court had jurisdiction to review at least some aspects of the military determination but that there was in this case a basis in fact for the denial. Despite this seemingly liberal approach, Judge Van Dusen continued to flirt with the lower court's view of nonreviewability and the stringent use of exhaustion in Noyd. Although stating that the

and face problems in the assignment of a conscientious objector claimant while the civilian courts were considering his case, and pointed to the superior efficiency of military tribunals in reaching a prompt and final decision. $I d$. The latter consideration is somewhat mitigated by the fact that federal courts are required to dispose of habeas corpus petitions without delay and that if petitioner were successful, injunctive rehef might be granted immediately.

151267 F. Supp. at 707-08.

152387 F.2d at 153 n.5. Unlike Capt. Noyd, Brown had already been court-martialed, but all his reviews and appeals and a possible petition for new trial had not yet been exhausted.

153 Id. at 152.

$154 I d$.

150 $I d$. at 153. In the court's view, factors such as that Brown made his claim only six weeks after enlisting and that his chaplain and commanding officer conditioned their opinions as to his sincerity indicated that 'Private Brown's petition presents no claim sufficiently unique, nor does his position slow such injustice, that we are compelled to interfere in whatever internal avenues of appeal are available to him within the Army." Id. at 154 . 
court need not decide whether complete exhaustion is always an indispensable prerequisite to the exercise of jurisdiction, ${ }^{156}$ he added in a footnote:

Claimed "conscientious objector" status can always be raised as a defense to prosecution for refusing to obey orders. From any judgment or sentence, comprehensive appeal is available. 10 U.S.C. $\$ \$ 817$, 859-876. This includes resort to a board of review (10 U.S.C. $\$ 866$ ), to the Court of Military Appeals (10 U.S.C. $\$ 867$ ), to the Secretary of the Army (10 U.S.C. $\$ 874$ ), and petition for a new trial (10 U.S.C. $\S 873)$. Appellant has not pursued all these available remedies. ${ }^{157}$

Judge Van Dusen's colleagues were in fundamental disagreement with respect to the question of jurisdiction. Judge Maris felt that the court had jurisdiction to review and that Brown was entitled to reversal on the merits, ${ }^{158}$ while Chief Judge Staley agreed with the lower court that the exercise of such jurisdiction was unduly disruptive of the operation of the armed forces and contrary to the doctrine of the separation of powers. ${ }^{159}$ Thus, Brown stands as something of a watershed, with all three positions expressed-the old absolute rule of nonreviewability, acceptance of reviewability, and the Noyd interpretation of the exhaustion rule. However, Judge Van Dusen's willingness to consider the case on the merits, despite his hesitation to express a view on the applicability of the exhaustion doctrine, was a break from the stringency of opinions like Noyd and Brown in the district court. One can only conjecture whether, if Judge Van Dusen had found no basis in fact for the denial of Brown's application, he would have granted the relief requested without full exhaustion of the court-martial appeals.

\section{Hammond v. Lenfest}

Hammond, who had enlisted in the U.S. Naval Reserve in 1963 when he was seventeen years old, became attracted to the Society of Friends while in college and in 1966 he became a member of a local "Meeting." On March 17, 1967, he submitted a request to the commanding officer of his reserve unit for a conscientious objector discharge. The request was denied by the Chief of Naval Personnel after the Director of the

156 ld. at 152.

157 Id. at 153 n. 5 .

$158 \mathrm{Id}$. at 154.

$159 \mathrm{ld}$. 
Selective Service System, General Hershey, rendered an adverse advisory opinion. Hammond refused to continue to attend reserve drills and was thereupon ordered to report for two years active duty. One week prior to the date on which he had been ordered to report, he filed a petition for writ of habeas corpus with the District Court for Connecticut, asserting that denial of his request for discharge was without basis in fact and violated the due process and equal protection clauses of the Constitution.

The district court, citing Orloff, Noyd and Brown, ruled that it had no jurisdiction over the case because Hammond had failed to exhaust the available administrative and military remedies. ${ }^{100}$ The Second Circuit reversed and remanded.161 After paying his respects to the nonreviewability doctrine at the outset of his opinion, ${ }^{162}$ Judge Kaufman went on to cite Burns v. Wilson ${ }^{103}$ as indicating "that in appropriate circumstances even a court martial proceeding-the ultimate method of enforcing discipline-could be reviewed in a civil court on an application for a writ of habeas corpus," 104 and Harmonv v. Brucker ${ }^{10 s}$ as authority that federal courts possess jurisdiction to review military discharges. ${ }^{166}$ Judge Kaufman's approach indicated that the old nonreviewability cases could no longer be relied upon to bar all review of military determinations, and thus a refusal to hear Hammond would have to be based on narrower grounds relating to the exhaustion of remedies.

After determining that Haminond, although not on active duty, was "in custody" so that habeas corpus would lie, ${ }^{167}$ Judge Kaufman considered the exhaustion question. Distinguishing Noyd as susceptible of being read as a mere application of the settled doctrine that the federal courts will not interfere with duty assignments of persons lawfully in the armed forces, ${ }^{108}$ the opinion further rejected any implication in Noyd

160 Opinion of Judge Zampano, D. Conn., has not been reported.

161 Hammond vi. Lenfest, 398 F.2d 705 (2d Cir. 1968).

162 Id. at 710, quating Orloff v. Willoughby, 345 U.S. 83, 93-94 (1953).

168346 U.S. 137 (1953).

164398 F.2d at 710.

165355 U.S. 579 (1958) (per curiam).

166398 F.2d at 710. The court also cited an address by Chief Justice Warren as questioning the policy of treating the military as an enclave beyond the reach of civilian courts. See Warren, The Bill of Rigbts and the Military, 37 N.Y.U.L. REv. 181, 188 (1962).

167398 F.2d at 711-12. But see United States ex rel. O'Hare v. Eichstaedt, 285 F. Supp. 476 (N.D. Cal. 1967).

168398 F.2d at 713. This same approach was taken in Crane v. Hedrick, 284 F. Supp. 250 (N.D. Cal. 1968), which was decided after the appeal in Hammond was argued 
that a court-martial is a prerequisite for federal court review of the claim that the petitioner, at the time of bringing suit, is not lawfully in the armed forces. By analogy to the state prisoner's right to habeas corpus, the court then noted that exhaustion was not an absolute bar to jurisdictional power:

[A] ssuming arguendo that Hammond's predicament can be analogized to that of a state prisoner petitioning for federal relief, it is settled that the doctrine requiring the exhaustion of available state remedies is not one defining power but one which governs the proper exercise of power, ... and is rooted in considerations of comity rather than in the scope of federal habeas corpus jurisdiction. ... ${ }^{169}$

Also recognizing the administrative law origins of the exhaustion doctrine, the court reasoned that if the court-martial is analogized to an administrative rather than a judicial remedy, "there is even less reason to require Hammond to be court martialled on the facts of this case." 170 The objectives of requiring exhaustion of administrative remedies, the court found, would not be met by requiring Hammond to subject himself to court-martial as a prerequisite to court review, for Hammond had already received the determination of General Hershey, the highest official in the administrative chain with the ultimate administrative expertise. Furthermore, resort to remedies in the court-martial area appeared to offer no real remedy for Hammond. He had no power to convene a court-martial, but even if one were convened, the court noted, there was no indication "that presenting a conscientious objector claim as a defense to a charge of violating military law by failing to

but before a decision was rendered. Crane involved an apprentice seaman who had enlisted in the Navy and, after a month of active duty, had applied for a conscientious objector discharge which was denied. He went AWOL just prior to the scheduled departure of his ship for Vietnam, and petitioned for habeas corpus seeking an order that he be discharged. After distinguishing Noyd, the court rejected the view of the exhaustion doctrine as requiring submission to a court-martial:

If respondents' contentions were to prevail, the only way one in petitioner's position could raise his constitutional claims of wrongful detention would be by first committing a crime and facing the possibility of imprisonment. Neither Congress nor the majority of the federal courts has been willing to exact that price of persons seeking such relief.

$284 \mathrm{~F}$. Supp. at 253 . The court made no further analysis of the policies which make the requirement of subjection to court-martial inappropriate, but the decision, coming at the moment that the Second Circuit was preparing its opinion in Hammond, no doubt lent support to a rejection of the Noyd rule.

169398 F.2d at 714.

$1701 d$. 
obey orders would be anything more than a futile and ritualistic gesture." 171

Judge Friendly's dissent relied heavily upon nonreviewability precedents, and argued further that since Hammond had voluntarily enlisted and enjoyed the privileges of reserve status for four and a half years, he should not now be relieved of the obligations. ${ }^{172}$ By placing special emphasis upon the contractual nature of voluntary enlistment, Judge Friendly raised the possibility that court interference with military discharge policies might have an adverse effect on military recruitment. Concerning the exhaustion question, he argued that it is incorrect to assume that a court-martial might not be convened since "there is little doubt that the Navy is ready to set its disciplinary machinery in motion if Hammond persists in refusing to report for active duty, once the district court lifts its stay." ${ }^{173}$ Furthermore, the court-martial would not be an exercise in futility since "[i]t would be well within the competence of a court martial to rule that, in the absence of evidence supporting General Hershey's 'advisory opinion,' it would follow the recommendation of Commanding Officer Lenfest . . . ."174 These contentions, if proven, would undoubtedly weaken the majority's argument. If it were a certainty that Hammond would be court-martialed and that full consideration would be given his claims of unlawful and unconstitutional demial of discharge, then the court-martial might provide an adequate remedy and might properly be viewed as a genuine remedial step which should be exhausted. However, it would still be questionable whether the additional courtmartial remedy should be grafted onto the administrative remedies, causing an almost endless chain of remedial hurdles.

Judge Friendly's arguments focus the debate essentially on the question of adequacy of remedy-whether the court-martial and its appeals would provide Hammond a full and fair review of the Secretary's administrative determination. Despite Judge Kaufman's suggestion that the Navy might not court-martial Hammond and thereby stall his appeal process, ${ }^{175}$ the true concern of the court appeared to be the fact that a different kind of tribunal, criminal in nature, had been added to the administrative chain of remedies and that the petitioner would

$171 \mathrm{Id}$. at 713 .

172 Id. at 717 .

173 Id.

174 Id.

$175 \mathrm{ld}$. at 714 . 
therefore be forced to take affirmative and unlawful action in order to obtain the ultimate remedy he sought. Indeed, even if the likelihood were strong that Hammond would be court-martialed, military law indicates that Hammond would not be able to raise the wrongful denial of his discharge at the military proceeding; ${ }^{176}$ in a recent review of the case of Captain Noyd, the Air Force Board of Review found no error in the fact that at his court-martial for failure to accept a duty assignment, Noyd was not permitted to raise as a defense the alleged unconstitutionality of the demial of a conscientious objector discharge. ${ }^{177}$ The military courts refused to entertain Noyd's claims on the grounds that only the federal courts had jurisdiction to review such administrative determinations. As Noyd himself expressed it:

The Air Force Board of Review did not "uphold" the requirement of universal pacifism for conscientious objection: it merely approved the court-martial's exclusion of this issue and the legality of the denial of my C.O. applications.

The distinction is not trivial. I have been before five courts and have yet to obtain a ruling on the merits. The Air Force successfully opposed my Federal court suit by arguing that proper forum was the military judiciary; now, with consummate agility, they maintain the converse. ${ }^{178}$

The Board of Review decision in Noyd would appear to weaken substantially the positions of Judge Van Dusen in Browwn ${ }^{179}$ and Judge Friendly in Hammond ${ }^{180}$ regarding the possibility of raising a conscien-

176 See United States v. Dunn, 38 C.M.R. 917 (1968); United States v. Taylor, 37 C.M.R. 547 (1966).

177 United States v. Noyd, A.C.M. 20,121 (Sept. 3, 1968), appeal docketed, No. 21,642, U.S.C.M.A., Jan. 23, 1969. The Air Force Board decision cited with approval, United States v. Dunn, 38 C.M.R. 917 (1968), in which the defendant had attempted to obtain review of the denial of a conscientious objector discharge at his court-martial for disobeying a lawful order:

The obvious answer is that such judicial review was not within the jurisdiction of the court-martial which tried the accused. The jurisdiction of a court-martial is a very limited jurisdiction derived from the power of the Congress, in Article I, Section 8, Clause 14, of the Constitution .... In its exercise of this power, the Congress did not include in the Uniform Code of Military Justice a grant of Id. at 920 . jurisdiction to military tribunals to review such administrative determinations.

178 N.Y. Times, Sept. 28, 1968, Letters to the Editor, at 32, col. 8.

179387 F.2d at 153 n.5.

180398 F.2d at 717. Violations of regulations concerning treatment of conscientious objector apphicants have been successfully raised as a defense to court-martial for 
tious objector claim as a defense in a court-martial for refusing to obey orders.

Even if this decision were reversed by the Court of Military Appeals ${ }^{181}$ and evidence of a wrongful denial of discharge were allowed as a defense in a court-martial, there is still considerable question whether an alleged conscientious objector should be forced to go into the criminal sphere to obtain a remedy and whether that renedy, if permitted, is adequate. Presumably the evidence would only be admissible with respect to a defense of justification for the act which brought about the court-martial. Such a defense would not necessarily involve a full

refusal to obey orders. E.g., United States v. Sigmon, C.M. 416,356 (Jan. 2, 1968) (in a court-martial for disobeying the order of a superior to board a bus which would transport him to a Vietnam-bound plane, soldier could claim as a defense that he had applied for a conscientious objector discharge and therefore could not, under Army regulations (AR 635-20), be moved from his unit or assigned duties in conflict with his beliefs); United States v. Quirk, C.M. 416,445 (May 31, 1968) (violations of AR 600-200 may be raised as a defense to court-martial for refusing to draw a weapon and join a platoon in drill).

181 On January 23, 1969, the Court of Military Appeals granted review of the Noyd court-martial, see note 139 supra, and one of the assignments of error is the Law Officer's exclusion of evidence concerning the wrongfulness of the Secretary's denial of a conscientious objector discharge. Certain considerations might work in favor of a reversal of the Board of Review's decision. The Court of Military Appeals has been particularly aware that if the military fails to provide opportunity for a fair review of arbitrary and unconstitutional military actions, there will be no recourse but to permit expanded collateral attacks on military determinations in the federal courts. See, e.g., United States v. Bevilacqua, 18 U.S.C.M.A. 10, 11-12, 39 C.M.R. 10, 11-12 (1968).

The fact that the military had granted virtually no conscientious objector discharges until the federal courts finally began to order discharges where there was no basis in fact for the demial has probably not escaped the Court of Military Appeals. The Central Committee for Conscientious Objectors advised in its liandbook: "[a]lthough many men were discharged on grounds of conscience previous to the Spring of 1966, since that time almost all discharges have been denied regardless of merit." CENTRAL ConramtTeE for Conscientious Objectors, Handbook for Conscientious Objectors 91 (10th ed. 1968). Statistics provided by the Department of Defense in November, 1968 (unpublished) show for the Army:

\begin{tabular}{|c|c|c|}
\hline Year & C.O. Discharge Applications & Discharges Approved \\
\hline 1961 & 8 & 1 \\
\hline 1962 & 5 & 2 \\
\hline 1963 & 69 & 29 \\
\hline 1964 & 62 & 30 \\
\hline 1965 & 101 & 26 \\
\hline 1966 & 118 & 5 \\
\hline 1967 & 185 & 9 \\
\hline 1968 thru Oct. & 264 & 44 \\
\hline
\end{tabular}

with slightly higher discharge percentages for the Navy and considerably higher for the Air Force. 
review of the administrative decision of the Secretary. Furthermore, the court-martial would have no particular expertise in determining the question of eligibility for a conscientious objector discharge, and indeed, reality suggests, as did petitioner Hammond, that there is a probability that a court-martial panel composed largely of military officers would be less than open-minded. ${ }^{182}$

While these considerations are inherently subjective in nature and thus difficult to evaluate, federal courts have often inquired into difficult questions concerning the adequacy of state appellate procedures and the fairness of state practices. ${ }^{183} \mathrm{~A}$ similar inquiry as to whether a courtmartial provides the conscientious objector an adequate forum for review would almost certainly appear to raise serious doubts about the validity of the process supported by the dissenting opinion in Hammond.

\section{$A$ Critique}

The foregoing decisions dealing with review of conscientious objector discharge denials have touched upon various aspects of the exhaustion of remedies doctrine without fully examining the policy considerations behind the doctrine. While the doctrine is clearly concerned with preserving the balance of authority between competing systems of decisionmaking, it does so by regulating the timeliness of court review rather than the ultimate availability of review. ${ }^{184}$ The objectives of exhaustion as applied to the military-federal court balance of authority seem to be threefold: First, to prevent premature court review which could upset the balance of power between the military (as a separate, functioning judicial and administrative system) and the civilian judiciary; second, to prevent interference with the efficient operation of the military judicial and administrative systems which could deny the military the

182 Brief for Appellant at 9, Hammond v. Lenfest, 398 F.2d 705 (2d Cir. 1968). The disciplinary philosophy is still present in the administration of courts-martial and, because of the compromise made in the Uniform Code of Military Justice of 1951, which left the administration of courts-martial under the control of commanders and failed to provide the serviceman with a jury of his peers, see Morgan, The Background of the Uniform Code of Military Justice, 28 Mmitary L. Rev. 17 (1965); Sherman, Revised Military Code: $A$ Qualified Assent, Trial 44, 46 (Dec.-Jan., 1968-9); Sherman, Military Injustice, 73 CASE AND CoMment 40-45 (July-Aug., 1968), there is some doubt as to whether servicemen can obtain adequate consideration of their conscientious objector beliefs from a court-martial.

183 H. M. Hart \& H. Wechsler, supra note 26 , at 510-17, 527-45.

184 See Fay v. Noia, 372 U.S. 391, 418 (1963); Jaffe, supra note 28, at 328. 
opportunity to exercise its expertise before resort to the courts; and third, to prevent inefficient use of judicial resources by requiring " $\mathrm{fi}$ nality" within the military judicial and administrative systems so that needless review can be avoided.

The first consideration appears to be the principal concern of decisions such as Brown, Noyd, and Judge Friendly's dissent in Hammond. By mixing nonreviewability language with the exhaustion doctrine, these opinions have expressed the concern that court review will rob the military of its autonomy and interfere with its operations. It appears, however, that phrasing the exhaustion doctrine in terms of complete denial of review is a misapplication of the doctrine. The exhaustion doctrine, with its historical functions of requiring finality before appellate review, exhaustion of legal remedies before granting equitable jnrisdiction, exhaustion of state remedies before granting federal habeas corpus, and exhaustion of administrative remedies before court review, does not bar jurisdiction but rather permits consideration of timing and comity by a court in deciding whether to exercise its proper jurisdiction and review a case at a particular time. A court applying the exhaustion doctrine has jurisdiction but chooses to withhold consideration of the issues until the completion of a foreign decisionmaking process. ${ }^{185}$ To the extent that the courts have relied on the total nonreviewability of military determinations, a concept that has been eroded in recent years, they have iguored their crucial role of weighing relevant facts and policy considerations in determining whether to apply the exhaustion doctrine.

Whether court review at a particular time will, in fact, rob the military of its rightful autonomy and interfere with its operations must be determined on the basis of the circumstances of each case. Relevant considerations might include, for example, the status of the petitioner. Hammond argued in his brief that he was only a reservist, rather than on active duty, and that his discharge would thus have a less disruptive effect on military manpower stability. ${ }^{186}$ Hammond also argued that because there was no indication that there are large numbers of in-service conscientious objectors, review would not substantially affect the military. ${ }^{187}$ This argument, however, does not take into consideration the possibility that if courts were to grant review freely to in-

185 See Gusik v. Schilder, 340 U.S. 128, 132 (1950); Ogden v. Zuckert, 298 F.2d 312, 317 (D.C. Cir. 1961).

186 Brief for Appellant at 9, Hammond v. Lenfest, 398 F.2d 705 (2d Cir. 1968). 187 Id. at 18. 
service conscientious objectors, the number of such applications would increase, a factor that a court must weigh in making its determination.

The possibility of delay and consequent misuse of military manpower as a result of premature court review is another relevant consideration for the court. This factor was cited in Brown both in favor of and against review. The district court argued that part of the armed forces would be rendered "immobile and entangled in litigation" 188 if federal court review were permitted, while the appellant in Hammond maintained that because habeas corpus petitions must be heard and acted upon promptly, the effect on the military would be insignificant. ${ }^{189}$

A further consideration in applying exhaustion is whether court review would, in fact, have an adverse effect upon military discipline and the efficient operation of military personnel programs. Because the military has a tendency to reject any change in the status quo as a threat to good order and discipline, ${ }^{190}$ courts must be wary of accepting arguments that military discipline will be destroyed if, for example, a conscientious objector can obtain court review and require the military to discharge him. Indeed, the argument has been made that conscientious objectors are rarely assimilated into the military and that disruption would in fact be reduced by a liberal discharge policy. ${ }^{191}$

A final relevant factor is the type of military determination which is being attacked. For example, cases seeking court review of a particular duty assignment or transfer overseas involve greater interference with the military than do cases seeking review of denial of a conscientious objector discharge, since duty assignments require more discretion by military authorities, and the potential for an avalanche of suits for review is greater.

It must be remembered that counterbalanced against the interest of the military in preserving its autonomy and effectiveness is the interest of the individual serviceman in having a prompt and effective means of protecting his rights. The balancing of the interests of the systen against those of the individual is present in administrative law, and is expressed in certain principles already mentioned: ${ }^{192}$ Exhaustion of

188263 F. Supp. at 692.

189 Brief for Appellant at 15, Hammond v. Lenfest, 398 F.2d 705 (2d Cir. 1968).

190 See, e.g., the comments by Professor Morgan, Chief Drafter of the UCMJ, regarding military opposition to the reforms embodied in the UCMJ. Morgan, supra note 182 .

191 See Macgill, Selective Conscientious Objection: Divine Will and Legislative Grace, supra note 146, at 1385.

192 See notes 80-85 supra and accompanying text. 
remedies is not necessary where the available remedies are inadequate, where irreparable injury would occur, or where constitutional rights are involved. These principles must be considered thoroughly in the military context.

As suggested above, there is substantial doubt as to whether a courtmartial will hear a conscientious objector's claim of improper denial, and whether such hearing, if allowed, would be adequate. The adequacy of the court-martial remedy is also affected by the promptness of available review. In Oestereich v. Selective Service System Local Board $11,{ }^{193}$ Justice Harlan recently agreed with the majority that a ministerial student who had been demied an express exemption from the draft was entitled to federal court review of the draft board's determination despite the existence of a federal statute forbidding review of board determinations. In his opinion, however, Justice Harlan suggested that the constitutionahity of a summary administrative deprivation of liberty may turn on the availability of a prompt, subsequent hearing. ${ }^{194}$ Applying this to the Oestereich case, Harlan determined that such hearing was not meaningfully provided by the option of defending a criminal prosecution for refusing to report for induction or filing a petition for a writ of habeas corpus after induction into the armed forces.

If this reasoning is applied to the situation in Hammond or Noyd, it surely raises doubts about the adequacy of the court-martial remedy for the in-service conscientious objector who desires to appeal the allegedly unconstitutional rejection of his discharge. Indeed, Captain Noyd's case, which is just now reaching the Court of Military Appeals more than a year after he was court-martialed, attests to the fact that the court-martial and its attendant appeals is a painfully slow process. The lack of a prompt disposition of an alleged wrongful administrative determination clearly affects the adequacy of the court-martial remedy and weighs in favor of permitting court review of these claims.

The principle that exhaustion is not required when it would occasion irreparable injuries, or when constitutional rights are involved, should also be considered in balancing the serviceman's interests against those of the military. Quite apart from the possible chilling effect on the exercise of constitutional rights, an effect created by postponing a serviceman's ability to obtain review, the petitioner himself may suffer irreparable injuries in the interim. He is subjected to the anxiety,

193393 U.S. 233, 239-44 (1968) (concurring opinion).

194 Id. at 243 n.6. 
discomfort, and possible expense of defending against criminal charges, and of being in an uncertain position for the considerable time required to exhaust the court-martial process. Furthermore, since a convicted serviceman is required to begin serving his sentence before his appeals are made, ${ }^{195}$ he may serve a substantial portion of his sentence before his remedies are finally exhausted and hence, before ever getting into a federal court. When constitutional issues are involved, one reason for waiving exhaustion is that administrative bodies often lack the expertise and authority to render a decision on constitutionality. For example, it has been suggested that both selective service boards ${ }^{196}$ and boards for correction of records ${ }^{197}$ are incompetent to determine questions concerning the constitutionality of an act of Congress. It would indeed be unreasonable to allow administrative tribunals and nonfederal court systems to make determinations regarding the constitutional validity of federal statutes ${ }^{198}$ if such determinations are to become effectively binding on litigants because of exhaustion requirements. Because the conscientious objector discharge suits have generally in-

195 Noyd v. Bond, 402 F.2d 441 (10 Cir. 1968), non-incarcerated status granted, 89 S. Ct. 478 (1968), cert. granted, 393 U.S. 1048 (1969).

196 Oestereich v. Selective Serv. Sys. Local Bd. 11, 393 U.S. 233, 242 (1968) (concurring opinion); Wills v. United States, 384 F.2d 943, 945 (9th Cir. 1967), cert. denied, 392 U.S. 908 (1968). In a recent case it was held inter alia that defendant, when prosecuted for refusal to submit to induction, could challenge the constitutionality of the draft laws although he had not raised this question before his draft board. "Whatever may be academic theory, no administrative agency, such as a draft board, believes it has the power or, practically, would exercise powver, to declare unconstitutional the statute under which it operates." United States v. Sisson, Crim. No. 68-237-W para. 6 (D. Mass, April 1, 1969) (Wyzanski, C.J.).

197 Nelson v. Miller, 373 F.2d 474, 480-81 (3d Cir. 1967), cert. denied, 387 U.S. 924 (1967). But see Craycroft v. Ferrall, 37 U.S.L.W. 2542 (9th Cir. March 5, 1969), holding that naval reservists who had been denied conscientious objection discharges must apply to the Navy Board for the Correction of Military Records before seeking federal court relief. There is considerable doubt as to the adequacy of the remedy offered by the Boards for the Correction of Military Records. Although an Air Force Board recently ordered the discharge of an airman who had been denied a conscientious objector discharge, David T. Bezouska, 1 SSLR 3163 (A.F. Bd. for Correc. of Mil. Rec. May 7, 1968), such boards have not generally given attention to corrective rehief until discharge is completed, Nelson v. Miller, supra at 479, and do not appear to possess the expertise required for review of in-service determinations such as refusal to grant a conscientious objector discharge, see note 103 supra. All the cases cited in Craycroft for the proposition that the boards are an administrative remedy which must be exhausted involved attempts to prevent discharge and findings that the boards provide an adequate post-discharge remedy for review and correction. Contra, Brooks v. Clifford, 37 U.S.L.W. 2542 (4th Cir. March 20, 1969); Gann v. Wilson, 289 F. Supp. 191 (N.D. Cal. 1968)

198 See generally H. M. HART \& H. WEChSLER, supra note 26 , at $136,523-27,539-45$. 
volved substantial attacks upon the constitutionality of both the federal statutory scheme and the regulations promulgated thereunder, a question is raised not only as to the competency of a court-martial to make such constitutional determinations, but as to whether the forced delay in obtaining a federal court determination is in keeping with the constitutional balance of powers and guarantee of individual rights.

As observed above, the basic function of the exhaustion doctrine in the military context is not only to balance military and civilian judicial power, but also to utilize fully administrative expertise and to insure finality. These latter objectives must also be considered in the light of the circumstances of each case. It would appear that whatever expertise the military has in processing conscientious objector discharges is exhausted in the determination made by the Adjutant General (after receiving the opinion of the Director of Selective Service), and that a court-martial convened to try a serviceman for refusing to obey orders has no special administrative expertise concerning the discharge issue. The argument that a court-martial itself offers additional expertise as it is composed of military men who are familiar with military problems overlooks the fact that a court-martial is basically a criminal court, and its function is distinct from that of the administrative scheme for processing discharge applications.

The objective of finality might be satisfied by judicial inquiry into whether the last administrative step which a petitioner has taken appears to be the logical end of available remedies from which he can obtain relief. Under this test, it might be argued that in Hammond the decision of the Adjutant General left no further step under the administrative scheme, while in Brown petitioner had been court-martialed and could have appealed the decision of that tribunal. In his opinion in Hammond, Judge Kaufman evidently believed this to be an inuportant distinction since he distinguished Gusik v. Schilder ${ }^{199}$ as a case in which the "petitioner had already been court martialed and the Court simply concluded that once that route had been traversed, it was incumbent upon him to exhaust his appeal to the Judge Advocate General." 200 Hammond, on the other hand, had no further step to take in the logical progression of his remedies. Unlike the strict approach to exhaustion in Noyd, which relies heavily upon principles of nonreviewability found in Orloff, this suggested approach would more easily permit consideration of both the appropriate principles of administrative 
law and the needs of the military in light of the unique circumstances of each case. Hammond $v$. Lenfest is a step in this direction because it offers, for the first time, an interest-balancing approach which is not preconditioned by the absolutes of nonreviewability. ${ }^{201}$

\section{The Effect of Hammond v. Lenfest on Other Types of Military Determinations}

Because Hammond appeared to reject the strict view of both the nonreviewability and exhaustion doctrines, it is viewed by many as evidence of a more liberal attitude by federal courts toward interference with the military, and will inevitably be cited as authority for permitting review of a wide variety of military determinations. The holding of the case, however, is restricted to its facts, and whether it will be applied by analogy to other areas is unclear.

The holding in Hammond has certain express limitations. First, in a per curiam opinion the decision was modified on a petition for rehearing and the case was sent back to the Department of the Navy to be processed in accordance with newly issued regulations ${ }^{202}$ dealing with

201 Subsequent decisions agreeing with Hammond have rejected the Noyd approach and tended to consider the competing interests in ruling on the requirement of exhaustion. In In re Kelly, 401 F.2d 211 (5th Cir. 1968), petitioner sought a writ of habeas corpus and stay of a court-martial for disobedience of orders, on the ground that the Army had frustrated and failed properly to process and grant his application for a conscientious objector discharge. The Fifth Circuit noted the split between the Noyd and Hammond circuits, and sided with Hammond:

But we view the requirement of exhaustion as did the majority in Hammond.

We consider it to be based on principles of comity and not as an imperative limitation of the scope of federal habeas corpus power.

401 F.2d at 213, accord, Cooper v. Barker, 291 F. Supp. 952 (D. Md. 1968); Gann v. Wilson, 289 F. Supp. 191 (N.D. Cal. 1968); Mandel v. Dayton, Civil No. 68-2695 (S.D.N.Y. Sept. 3, 1968). However, the Fifth Circuit found that this was not a proper case for the exercise of habeas corpus power since court-martial proceedings were already pending and the record did not clearly support the claim of "no basis in fact" for denial.

202 DOD Directive 1300.6 (May 10, 1968), see note 118 supra. It appears unlikely that the new right to appear before an officer of O-3 or higher will make much difference in the processing of conscientious objector cases. It will simply add one more individual's recommendations to those of a chaplain, psychiatrist and commanding officer. It does permit the applicant to present information to the officer and to be represented by a civilian attorney if desired, but it does not appear to be intended to provide a hearing aimed at making determinations of fact since the department official in the Pentagon still has full authority to make initial fact-findings and render conclusions of law. The provision for hearing before an officer appears to have been added to the regulations as a stop-gap measure to meet some of the objections being raised in federal suits against the insufficiency of conscientious objector review pro- 
conscientious objector discharges. ${ }^{203}$ While this decision prevented Hammond's discharge, it remained consistent with the original opinion, for it evidenced a willingness to accept jurisdiction over conscientious discharge cases pending exhaustion of all available administrative remedies within the military.

Second, Hammond indicated that it was not altering the traditional nonreviewability doctrine by distinguishing Noyd as a case attempting to interfere with "duty assignments of persons lawfully in the armed forces." ${ }^{204}$ Although the distinction appears to be somewhat strained, ${ }^{205}$ it permitted the court to avoid a holding directly contrary to Noyd, and more importantly, to distinguish Orloff. It is understandable that a circuit court would desire to avoid conflict with a decision as widely accepted as Orloff, and by distingnishing that case it was actually able to encroach upon Orloff's venerable doctrine. ${ }^{206}$ Although Orloff used rather broad language ${ }^{207}$ and has been cited for still broader notions of nonreviewability, its holding was that "it is not within

cedures and was not made with a view toward establishing an administrative system with opportunities for plenary hearings and rehief.

203398 F.2d at 718. One month after the original Hammond opinion was decided, a different Second Circuit panel in United States ex rel. Mankiewicz v. Ray, 399 F.2d 900 (2d Cir. 1968), ruled on another habeas corpus petition by a reservist seeking review of a denial of his conscientious objector application by the Navy. The court reversed the district court's denial of review, but remanded with instructions that Mankiewicz be reprocessed by the Navy under new DOD Directive procedures. This had the effect of deferring court-martial proceedings which were pending until determination was made under the new procedures. Judge Friendly concurred in the reversal but stated that he "would feel bound to object to an extension of Hammond . . . to a case where a court-niartial had already been convened and there was no adequate showing that it would not consider Mankiewicz' defense." Id. at 902.

204398 F.2d at 713.

205 There appears to be no basis for treating Noyd's suit to require assignment to duties consistent with his beliefs as different from Hammond's suit to prevent activation which would result in assignment to duties inconsistent with his beliefs.

206 The expansion of review in discharge cases in the 1950's and 1960's was also accomplished without actually admitting to incursions on the nonreviewability doctrine. However, unlike the Harmon v. Brucker type of discharge suit which sought alteration of records after discharge had been accomplished, or the court-martial review cases like Burns v. Wilson which reviewed courts-martial proceedings after the fact, Hammond directly affected the status of personnel presently in the military. See also Schwartz v. Covington, 341 F.2d 537 (9th Cir. 1965), enjoining issuance of undesirable discharge and insuring present rank and status, pending petition to correction boards, on grounds that petitioner had shown likelihood he would ultimately prevail, would suffer irreparable injury if discharged (even if later reinstated) and there would be no irreparable injury to the government.

207 See, e.g., text at note 65 supra. 
the power of this Court by habeas corpus to determine whether specific assignments to duty fall within the basic classification of petitioner." 208 Indeed, there are cogent reasons why the courts should not review duty assignments, which require considerable administrative discretion, ${ }^{208}$ for if courts accepted such cases, every serviceman would be a potential hitigant, and review could result in virtual day-to-day court control of the military. In contrast to this dilemma, however, court review of denial of a conscientious objector discharge requires consideration of ouly one basic factual determination which does not require substantial administrative discretion-whether the applicant's beliefs are sincere. Furthermore, there are a much smaller number of potential hitigants, and court action, although it would interfere with military manpower, ${ }^{210}$ would not interfere with day-to-day military operations. Thus, there are practical reasons why the Orloff doctrine should not apply to conscientious objector discharge determinations. Such practical considerations clearly prompted the Hammond court to limit its original holding:

Specifically, we have not held that a decision based on military exigencies refusing to discharge a serviceman lawfully in the armed forces -the situation that would have been presented, for example, if a soldier on a battlefield during World War II had been refused a discharge because of the needs of the service-is subject to judicial review. The federal courts have neither appropriate judicial standards nor the capacity for dealing with such questions. ${ }^{211}$

It is difficult to ascertain precisely which elements mentioned by Judge Kaufman-lawful status in the armed forces, a battlefield situation, the existence of military exigencies-would make judicial review inappropriate. Surely Hammond was "lawfully in the armed forces" so this consideration alone does not seem determinative. Apparently, the court meant that only extreme situations involving battlefield conditions or serious military exigencies would prevent court review of a military -denial of a conscientious objector discharge.

Most of the recent suits involving the concepts of exhaustion or nonreviewability have sought review of one of four types of military determinations: duty assignments, denial of discharge, activation orders,

208345 U.S. at 93.

209345 U.S. at $94-95$.

210 See note 206 supra.

211398 F.2d 705, 716 (2d Cir. 1968). 
or convening of courts-martial. The implications of Hammond will be discussed with respect to each of these areas.

\section{Duty Assignment Cases}

Duty assignment cases prior to Hammond were generally dismissed on grounds of nonrevietvability. In Luftig v. McNamara, ${ }^{212}$ for example, an Army private sought declaratory and injunctive relief to prevent the Army from shipping him to Vietnam, asserting that American military action there was illegal and unconstitutional and that there was no lawful authority to assign him there. The district court dismissed on the ground that review of political questions was beyond its jurisdiction. On appeal the D.C. Circuit affirmed, stating:

It is difficult to think of an area less suited for judicial action. . . The fundamental division of authority and power established by the Constitution precludes judges from overseeing the conduct of foreign policy or the use and disposition of military power; these matters are plainly the exclusive province of Congress and the Executive. ${ }^{213}$

While cases of this type ${ }^{214}$ made it clear that direct attacks on the legality or constitutionality of the war would not be heard by the courts, plaintiffs have more recently relied, witl limited success, on other grounds. Thus, a lieutenant who was active in organizing a peace march was granted a stay by Justice Douglas to prevent his sudden shipment to Formosa, ${ }^{215}$ while anotler officer was granted a hearing, but denied a temporary restraining order, when he sought to prevent his shipment to Vietnam on the ground that under Army regulations he had to be retained in his unit until a determination was made with respect to his application for a conscientious objector discharge. ${ }^{210}$ Neither case, however, resulted in a merits determination on the jurisdictional issue. In other recent suits the Orloff doctrine preventing review of duty assignments has been held dispositive of the jurisdic-

212373 F.2d 664 (D.C. Cir. 1967).

213 Id. at 665-66.

214 A similar suit was brought in Mora v. McNamara, 389 U.S. 934 (1967), by three soldiers ("The Fort Hood Three") just prior to their scheduled departure for Vietnam, seeking to enjoin the Secretary of Defense froin carrying out their orders, and to obtain a declaratory judgment that the United States military activity in Vietnam is unlawful. After the circuit court dismissed for lack of jurisdiction, the Supreme Court denied certiorari, despite dissents by Justices Stewart and Douglas.

215 Smith v. Ritchey, 89 S. Ct. 54 (1968).

216 Earl v. Cushman, Misc. Civil No. 68-1164-J (D. Mass. Dec. 18, 1968). 
tional issue. In Weber $v$. Clifford, ${ }^{217}$ a suit by a soldier with a history of rheumatic fever, seeking to set aside Army orders for Vietnam, was dismissed on the grounds that the district court had no jurisdiction to review a determination made by Army doctors. Similarly, in McAbee $v$. Martinez, ${ }^{218}$ the district court determined that it lacked jurisdiction in a suit brought by members of an activated army reserve unit who claimed they had not received adequate training for overseas duty and sought to have orders for shipment to Vietnam enjoined on that ground.

One suit, Noyd $v$. Bond, ${ }^{219}$ has successfully obtained district court review of and relief from a duty assignment. After Captain Noyd was convicted by a court-martial and sentenced to dismissal, total forfeitures, and confinement at hard labor for one year, the convening authority, following customary procedures, directed that he be transferred to the disciplinary barracks at Ft. Leavenworth. Noyd sought a writ of habeas corpus in the District Court for the District of New Mexico claiming that the order violated Article $71(\mathrm{c}), \mathrm{UCMJ},{ }^{220}$ which provides that no sentence of a punitive discharge or one year's confinement may be executed until affirmed by a board of review. In Noyd v. Bond, the district court held that while it had no jurisdiction to determine the conditions of military confinement, under habeas corpus it could test the legality of a present order, including one involving a sentence to be served in the future. It also found

217289 F. Supp. 960 (D. Md. 1968).

218291 F. Supp. 77 (D. Md.), injunctive relief denied, 393 U.S. 904 (1968). In Martinez the principal claim was that the overseas orders violated Army regulations (AR 612-35) requiring certain types of training before overseas deployment, and requiring removal of personnel "not qualified to perform duties" in their MOS (job category) from units being shipped overseas. The district court dismissed on the grounds that the Army rather than the courts should determine MOS qualifications since court review would require testimony of witnesses from widely divergent areas of the world, and that petitioners had not exhausted their administrative remedies through the Inspector General Complaints System (AR 20-1, ch. 3). This requirement that a serviceman seek rehief through the Inspector General (an officer in each command who acts as a sort of ombudsman for hearing of grievances and complaints) seems particularly unsuitable to the exhaustion doctrine, since the Inspector General has no power to provide a remedy for an individual. He merely constitutes another time-consuming and probably inefficacious step before genuine remedies can be sought.

219285 F. Supp. 785 (D.N.M. 1968).

220 The Government contended that since under Article 57 (b), UCMJ, the period of confinement runs from the date of sentence, immediate confinement is authorized. The court, however, found that Article 71 (c) is an exception to Article 57(b). Id. at 787. 
that due to the Air Force's determination to execute the sentence, the military process was ineffective to protect petitioner's rights and so adequate grounds existed for not applying the exhaustion of remedies requirement. ${ }^{221}$ The Tenth Circuit reversed, ${ }^{222}$ holding that because the case was pending before a board of review, Noyd had not exhausted his military appellate remedies. The court further stated that the Court of Military Appeals had power to grant habeas corpus relief under these circumstances. ${ }^{223}$ The problem with this analysis is that a board of review determines only those issues relevant to the court-martial, ${ }^{221}$ and it is unlikely that it would review or grant relief of claims concerning the conditions of incarceration imposed after completion of a court-martial. The contention that the Court of Military Appeals could grant rehef and therefore provide a remedy which must be exhausted is also tenuous. Despite recent assertions by the CMA concerning its extraordinary relief powers ${ }^{225}$ aimed at broadening

221 See Smith v. Resor, 406 F.2d 141 (2d Cir. 1969), where review and relief were granted despite failure to utilize the right to make a complaint under Article 138 and through the Inspector General because the commanding officer had indicated that there were no other remedies. But see Levy v. Dillon, 286 F. Supp. 593 (D. Kan. 1968), which declined to follow Noyd and demied release, on habeas corpus, from disciplinary barracks and rehef from allegedly improper treatment, despite the fact that appeal to a board of review was not completed, on grounds, inter alia, that petitioner had not exhausted his military remedies by making complaint to his commander under Article 138, UCMJ, and that Article 71(c) was not applicable because, until affirmance by a board of review, sentence has not been "executed."

222402 F.2d 441 (10th Cir. 1968).

223 The court cited Levy v. Resor, 17 U.S.C.M.A. 135, 37 C.M.R. 399 (1967), which stated that it could grant extraordinary relief but rejected petitioner's request for bail on the grounds that servicemen have no constitutional right to bail. See also Levy v. Resor, 384 F.2d 689 (4th Cir. 1967) (per curiam), cert. denied, 389 U.S. 1049 (1968) (denial of subsequent application for habeas corpus to procure release on bail and grant of application by government to move petitioner to disciplinary barracks at Ft. Leavenworth upheld on review).

224 Art. 66, UCMJ.

225 In Gale v. United States, 17 U.S.C.M.A. 40, 37 C.M.R. 304 (1967), the Court of Military Appeals declared that it possesses "all writ" powers and could exercise, by means of extraordinary remedies, general supervisory control over military justice. See also United States v. Frischholz, 16 U.S.C.M.A. 150, 36 C.M.R. 306 (1966). In United States v. Bevilacqua, 18 U.S.C.M.A. 10, 39 C.M.R. 10 (1968), involving a petition to the CMA for writ of error coram nobis by petitioners who had been convicted in a special court-martial which did not meet the requirements of Article 67, UCMJ, for court review, the court stated that although its jurisdiction regarding direct appeals was conditioned by Article 67, that Article does not describe the full panoply of its powers and that Congress intended it to have power to grant relief on an extraordinary basis when an accused has been palpably deprived of his constitutional rights in a military trial. 
its powers under the Uniform Code of Military Justice, ${ }_{2}^{26}$ that tribunal is vested only with the power to review court-martial convictions. ${ }^{227}$ There remains considerable confusion as to the extent of its powers and the adequacy of the CMA as a remedy in many circumstances. ${ }^{228}$

Early in 1969, the Supreme Court granted certiorari in Noyd $v$. Bond. ${ }^{229}$ In granting non-incarcerated status Justice Douglas stated that the suit does not challenge purported error in a court-martial, which would require that court-martial appeal remedies first be exhausted, but that it raised questions as to whether exhaustion of remedies applies in cases where it is claimed that court-martial authorities acted beyond their authority. ${ }^{230}$ Furthermore, he noted that it presents questions as to the scope of review of the Court of Military Appeals. The case thus involves important questions concerning the nonreviewability and exhaustion of remedies doctrines in relation to military orders. Justice Douglas has already expressed the opinion, in his dissent in Morse $v$. Boswell, ${ }^{231}$ that Orloff is limited to the case where the military has acted

226 There is indeed good reason for the CMA to attempt to broaden its powers, for the unavailability of extraordinary remedies within the military system has caused many petitioners to seek relief in federal courts. See notes $6-14,66$ supra and accompanying text.

227 Art. 67, UCMJ.

228 Despite its assertions of expanded relief powers the CMA almost universally denies extraordinary relief. This author's examination of the Miscellaneous Docket, United States Court of Military Appeals shows:

Dismissed for Jurisdiction

Lack of Granted, but

\begin{tabular}{|c|c|c|c|c|}
\hline & Suits Filed & Jurisdiction & Relief Demied & Relief Granted \\
\hline $1966^{\mathrm{a}}$ & 2 & 2 & & \\
\hline 1967 & 24 & 7 & 14 & $3 \mathbf{b}$ \\
\hline 1968 & 20 & 6 & 13 & $1 \mathrm{c}$ \\
\hline
\end{tabular}

a The docket was established in October, 1966.

b The three cases, United States v. Board of Review \#2, \#1, \#4, 17 U.S.C.M.A. 150, 37 C.M.R. 414 (1967), sought relief, on habeas corpus, where there had been command influence. The court returned the cases to the boards for disposition in accordance with United States v. BuBay, 17 U.S.C.M.A. 147, 37 C.M.R. 411 (1967).

c Jones v. Ignatius, Misc. No. 68-14, holding, on motion for extraordinary relief, that commutation of special court-martial sentence by convening authority to 11 months confinement at hard labor was beyond jurisdiction of special courtmartial.

d Through March 6, 1969.

e 2 cases pending without determination.

22989 S. Ct. 692 (1969).

23089 S. Ct. 478 (1968).

231393 U.S. 802,809 (1968). 
within its powers in denying petitioner an assignment, and does not apply where it acts without such power. However, Noyd v. Bond is not a typical assignment or order case because the order to confinement is closely related to court-martial proceedings, and disposition of convicted servicemen is governed by the UCMJ, unlike the normal case involving duty assignment where the military's authority is highly discretionary and therefore less likely to be disturbed. ${ }^{232}$ Nevertheless, the Noyd case still raises doubts regarding the absoluteness of the nonreviewability doctrine as applied to military orders, and raises the possibility of a general movement toward court review of orders involving abuse of autlority-orders issued in an arbitrary or discriminatory manner, or intended to prevent exercise of first amendment rights, or in clear violation of military regnlations.-

\section{Cases Involving Denial of Discbarge}

The few post-Hammond suits seeking review of a denial of discharge have similarly been dismissed on grounds of nonreviewability. In Rank v. Gleszer, ${ }^{233}$ for example, a National Guard member was denied a writ of habeas corpus to require his discharge for physical unfitness on the gronnds that the statutory provisions governing discharge gave the appropriate Secretary discretionary authority and, absent compelling considerations such as a first amendment claim or a claim that the military exceeded its authority, the courts will permit the military "to solve its own problems within its administrative system." 234

The Rank court also noted that petitioner had not exhausted his administrative remedies within the military. The exhaustion doctrine is particularly confused in the area of administrative discharges because the administrative scheme is often not clearly defined, and thus it is often uncertain what authority each of the relevant boards and individuals possess. ${ }^{235}$ Furthermore, since an administrative discharge is con-

232 See Arnheiter v. Ignatius, No. 48414 (N.D. Cal. 1968), quoted in 115 Cong. Rec. E 545-50 (daily ed. Jan. 28, 1969), where the district court refused to intercede in the removal of an officer from command of a destroyer escort. The court stated that although Burns and Harmon had relaxed the traditional nonreviewability rule, neither court-martial, punitive action nor demotion were involved in the instant case, and thus judicial review was not appropriate for "such purely internal, administrative matters as duty assignment and promotion." However, the court declined to rest its holding on nonreviewability and denied relief on the merits.

233288 F. Supp. 174 (D. Colo. 1968).

234 Id. at 175.

$235 \mathrm{See}, e . g$, id. at 176 (expressing uncertainty concerning the significance of de- 
sidered a discretionary action in the best interests of the service, ${ }^{236}$ there is no precedent for court review of military refusal to discharge a serviceman who claims grounds for discharge, such as minority, dependency or hardship, physical or mental disability, or unsuitability or unfitness. However, when a refusal to take administrative discharge action or to grant a discharge involves arbitrariness or discrimination, a first amendment claim, or violation of military authority or regulations, there would seem to be reason for permitting court review once the serviceman has exhausted all hope of relief from the military authorities. ${ }^{237}$

\section{Suits Involving Activation Orders}

A number of suits seeking-review of activation orders were filed by

terminations by such administrative tribunals as Physical Evaluation Board, Physical Review Council, and Physical Disability Appeal Board).

236 See DOD Directive 1332.14, pt. V, para. A; AR 635-212 (Personnel Separations: Discharge, Unfitness \& Unsuitability), para. 10 (unit commander will recommend whether action for discharge, disposition through medical channels, or disciplinary action should be initiated); AR 635-40 (Physical Evaluation for Retention, Retirement or Separation); AR 635-200 (Personnel Separations: Enlisted Personnel). For Congressional investigation into criticisms of the administrative discharge system, see Joint Hearings, supra note 103 , at 769-836.

237 When a serviceman seeks release from the military by habeas corpus, not on the grounds that he is entitled to a discharge, but that he was unlawfully inducted, see text at notes 31-35 supra, there are different exhaustion considerations. The services have provided procedures for dealing with servicemen who claim wrongful induction. For example, AR 635-200, ch. 5, Sec. III, para. 5-5, permits apphication for discharge through military channels for "an individual claiming erroneous induction because of denial of a procedural right." Cases have held that a serviceman must exhaust his inservice remedies, even if claiming unlawful induction, Pickens v. Cox, 282 F.2d 784 (10th Cir. 1960); United States ex rel. Tomback v. Bullock, 110 F. Supp. 698 (N.D. III. 1953). On the other hand, there is authority that since the military lacks valid jurisdiction over one wrongfully inducted, he need not exhaust in-service remedies, United States ex rel. Ursitti v. Baird, 39 F. Supp. 872 (E.D.N.Y. 1941). A nunIber of decisions have granted habeas corpus retief, despite failure to exhaust inservice remedies, without raising the exhaustion issue. E.g., Powers v. Powers, 400 F.2d 438 (5th Cir. 1968); United States ex rel. Wilkerson v. Commanding Officer, $286 \mathrm{~F}$. Supp. 290 (S.D.N.Y. 1968); United States ex rel. Caputo v. Sharp, 282 F. Supp. 362 (E.D. $\mathrm{Pa} .1968$ ). The issue is currently being hitigated in a case pending before the District of Massachusetts, involving au application for writ of habeas corpus on the ground that the Army violated its regulations in failing to give proper medical examination and consideration at induction to an inductee with a history of hypertension who had been wrongly classified $1-\mathrm{A}$. The government argued that the court lacked jurisdiction because of petitioner's failure to exhaust remedies under AR 635-200 and the Selective Service System, and argued further that the inductee had waived any alleged induction procedural irregularities. Gross v. Commanding Officer, Misc. Civil No. 68-79-J (D. Mass. 1968). 
members of reserve and national guard units activated during the 1968 call-ups. Except for stay orders issued by Justice Douglas ${ }^{238}$ and ten1porary restraining orders issued by some lower courts, ${ }^{239}$ the activation orders were upheld. However, jurisdiction was generally accepted by the district courts and the determinations made on the merits. In Morse v. Boswell, ${ }^{240} 113$ members of an activated reserve unit sought to prevent assignment overseas and to cancel activation on the grounds that the statute under which they were activated, ${ }^{241}$ passed after they had entered their enlistment contracts, violated those contracts and violated the equal protection clause of the Constitution and the doctrine of separation of powers. The Government did not contest jurisdiction and the claim was heard and rejected on the merits. Since these suits attacked the constitutionality of a federal statute, and there was no administrative scheme providing further remedies for appeal, the grant of jurisdiction would seem correct.

Another type of activation suit, challenging the activation of individual reservists, has experienced basic jurisdictional problems. Three recent Second Circuit decisions, each decided by a different panel, have dealt with these problems. Fox v. Brown $n^{242}$ was an action by an Air National Guard reservist to annul an order directing him to report for active duty because of his unsatisfactory attendance at reserve meetings. Relying upon Orloff and distinguishing Hammond, the court held that there was no justiciable claim within its jurisdiction because the suit sought review of acts of military discretion which affected the status of persons in the armed forces. It indicated, however, that review is permissible to determine whether the military had acted within its jurisdiction under valid law, ${ }^{243}$ and might be permissible in cases involv-

238 See, e.g., Winters v. United States, 89 S. Ct. 57 (Douglas, Circuit Justice, 1968); Smith v. Ritchey, 89 S. Ct. 54 (Douglas, Circuit Justice, 1968).

239 A Temporary Restraining Order was granted by the U.S. District Court for the Central District of California in Sofen v. McNamara, Civil No. 68-239-AAH (1968); Frohmuth v. United States, Civil No. 68-571-WPG (1968); Most v. United States, Civil No. 68-886-PH (1968); Ali v. United States, 289 F. Supp. 530 (C.D. Cal. 1968). Gion r. McNamara, Civil No. 68-986-S (C.D. Cal. Jan. 9, 1968), held that involuntary activation pursuant to 10 U.S.C.A. $\$ 263$ (Supp. 1969), violated the enlistment contract and the Constitution and ordered the activation rescinded.

240289 F. Supp. 812 (D. Md.), aff'd, 401 F.2d 544 (4th Cir.), stay denied, 393 U.S. 802 (1968), cert. denied, 89 S. Ct. 687 (1969). Cf. Pfile v. Corcoran, 287 F. Supp. 554 (D. Colo. 1968).

24110 U.S.C.A. $\$ 263$ (Supp. 1969).

242402 F.2d 837 (2d Cir.), aff'g 286 F. Supp. 855 (S.D.N.Y. 1968).

243 Id. at 840, citing Winters v. United States, 281 F. Supp. 289 (E.D.N.Y.), aff'd per curiam, 390 F.2d 879 (2d Cir.), stay denied, 391 U.S. 910, cert. denied, 393 U.S. 896 
ing administrative decisions which had a chilling effect on first amendment rights. ${ }^{244}$ A second decision, United States ex rel. Schonbrun $v$. Commanding Officer, ${ }^{245}$ involved a reservist's petition for writ of habeas corpus to prevent his activation on the grounds of "extreme personal and community hardship." ${ }^{246}$ While the court expressed uncertainty as to whether habeas corpus could be used to attack activation, ${ }^{247}$ it ruled that mandamus pursuant to 28 U.S.C. $\S 1361$ is available in such a situation if the military has not acted within its jurisdiction and the official conduct goes "far beyond any rational exercise of discretion." ${ }^{248}$ The court found, however, that violation by the Army of its own regulations did not in this case prejudice the petitioner and denied review because of the need for expedition in the administration of military personnel and for avoidance of undue court interference. In a third decision, Smith $v$. Resor, ${ }^{249}$ Judge Kaufman refused to review the "discretionary orders" activating an Army reservist who had been given unsatisfactory ratings for attendance at reserve meetings because he had long hair. However, he ruled that since Army regulations permit long hair if it contributes to one's civilian livelihood (petitioner played in a musical group), and since the record of the case clearly showed that at several crucial stages the Army failed to follow its own procedures and safeguards, the case should be sent back to the Army with orders that the petitioner be permitted "fully to avail himself of the procedures the Army has established for review . . . ." 250

These cases appear to present attempts by the Second Circuit to find a workable approach to the extension of Hammond. Since different panels have decided the cases there is less uniformity and continuity than there might be. Thus, despite the functional interest-balancing approach to reviewability and exhaustion which first appeared in

(1968). But see Quaid v. United States, 386 F.2d 25 (10th Cir. 1967) (delinquent reservist entitled to have local board investigate claim of conscientious objection before induction), distinguished, Even v. Clifford, 287 F. Supp. 334, 337-38 (1968).

244402 F.2d at 840 .

245403 F.2d 371 (2d Cir. 1968), reconsideration of denial of stay denied, 89 S. Ct. 609 (1969).

246 Id. at 372.

247 The court stated that habeas corpus cannot be used to test the conditions of lawful custody except where challenging the legality of a change from probation or parole to imprisonment. It expressed uncertainty as to whether activation falls within this exception. Id. at 374 .

$248 \mathrm{Id}$.

249 Smith v. Resor, 406 F.2d 141 (2d Cir. 1969).

250 Id. at 145-46. 
Hammond, reliance on absolute statements of nonreviewability continue to crop up, such as the statement in Fox that the courts lack jurisdiction to review acts of military discretion or to affect the status of military personnel. Nevertheless, the cases indicate that where the administrative action exceeds legal authority ${ }^{251}$ or is "beyond any rational exercise of discretion" 252 or has a chilling effect on first amendment rights, ${ }^{253}$ review may be permissible. These factors must, of course, be weighed against the military's interest in accomplishing a rapid and efficient call-up of reserves or in maintaining an effective reserve program by use of pumitive activation for delinquent reservists. The degree of interference with the military will necessarily differ according to variables such as the type of military action involved and the status of the reservist. For example, court review of the punitive activation of a reservist who claims that his orders violate military regulations would involve less interference with the military than the review of activation of an entire unit. Infringement on individual rights might also be of less consequence in the unit activation since such a wholesale activation is an accepted and omnipresent threat for a reservist. While the fear that the courts will be flooded with suits ${ }^{254}$ continues to impede adoption of a more hberal review policy, it is clear that the Orloff doctrine of nonreviewability is no longer an absolute.

\section{Suits to Enjoin Courts-Martial}

Suits to enjoin the military from holding a court-martial have been unsuccessful, primarily because of failure to exhaust military remedies. In Gorko v. Commanding Officer, ${ }^{255}$ the Tenth Circuit refused a writ of habeas corpus to prevent the military from trying petitioner a second time following the reversal of his first conviction:

Exhaustion of all available military remedies is required before reliance may be had on habeas corpus. The Uniform Code of Military Justice provides that no person, without his consent, may be tried a second time for the same offense. The adequacy and availability of

251 See text at note 243 supra.

252 See text at note 248 supra.

253 See text ar note 244 supra.

254 See United States ex rel. Schonbrun v. Commanding Officer, 403 F.2d 371, 375 (2d Cir. 1968).

255314 F.2d 858 (10th Cir. 1963). 
the military remedy is not questioned. Consideration of the question by the courts is, accordingly, premature. ${ }^{256}$

Other attempts to enjoin a court-martial have relied for authority on Dombrowski v. Pfister. ${ }^{257}$ In Levy v. McNamara, ${ }^{258}$ for example, the plaintiff sought to prevent the military from bringing him to trial for activities allegedly protected by the first amendment. Although the suit was dismissed for lack of jurisdiction, it would appear that such a case involves many of the same considerations which led the Supreme Court in Dombrowski to interfere with the autonomy of the state courts by enjoining prosecutions which would have a chilling effect on the right of expression. Indeed, as the traditional view of the autonomy of the military continues to change, extension of Dombrowski to the military appears appropriate.

Lilkewise, under a Hammond interest-balancing approach, there are compelling reasons for court review of the administrative decision to convene a court-martial when it is in clear violation of statutory authority, military regulations, or constitutional rights. Recent conscientious objector discharge suits have successfully prevented courts-martial by granting relief from prior administrative determinations denying conscientious objector discharges. Courts have ordered that pending court-martial proceedings be deferred until final administrative determination regarding discharge has been made, ${ }^{259}$ and have ordered a petitioner discharged as a conscientious objector despite pending offenses ${ }^{260}$ and court-martial proceedings. ${ }^{261}$ Nevertheless, hesitancy to interfere

256 Id. at 860 .

257380 U.S. 479 (1965). See note 146 supra.

258 Civil No. 953-67 (D.D.C.), aff'd sub nom. Levy v. Corcoran, 389 F.2d 929 (D.C. Cir.), stay denied, 387 U.S. 915, cert. denied, 389 U.S. 960 (1967). A similar suir to prevent the court-martial of 25 soldiers for mutiny who had staged a peaceful stockade sit-down strike was taken under advisement and the courts-martial permitted to be held. Hallinan v. Secretary, described in N.Y. Times, Nov. 27, 1968, at 23, col. 6; Jan. 25,1969 , at 56, col. 6 .

259 United States ex rel. Mankiewicz v. Ray, 399 F.2d 900 (2d Cir. 1968).

260 Crane v. Hedrick, 284 F. Supp. 250 (N.D. Cal. 1968).

261 Cooper v. Barker, 291 F. Supp 952 (D. Md. 1968). Although there had been no final administrative determination on petitioner's application for conscientious objector discharge and court-martial charges of AWOL and refusal of an order to put on a uniform were pending, the court found that "the Navy was refusing to complete processing and was insisting instead that court-martial proceedings of petitioner be completed first" and in view of these circumstances, the Court held that "there has been no failure by petitioner in this case to exhaust his available administrative remedies because the Navy has refused to permit him to do so." $291 \mathrm{~F}$. Supp. at 959. 
with the military's judicial system remains a serious obstruction to court injunctions against the holding of courts-martial.

In summary, it is likely that the availability of federal court review of the above types of military determinations will continue to depend upon narrow exceptions to the nonreviewability rule. There are precedents for permitting review of and rehief from certain military determinations when a challenge is made regarding the constitutionality of an act of Congress, ${ }^{262}$ when the military is acting "far afield of its statutory powers," ${ }^{203}$ far beyond any rational exericse of discretion ${ }^{264}$ or in violation of its own regulations, ${ }^{205}$ and when first amendment rights are involved. ${ }^{266}$ These categories embody considerations of policy, and to the extent that they permit a functional analysis of the circumstances involved in an individual case, they should provide a salutary extension of court review of military determinations.

\section{Conctusion}

During the Vietnam War, the exhaustion of remedies doctrine has undergone a tortured development in relation to court review of military determinations. The rejection of the strict rule of Noyd $v$. McNamara by the Second Circuit in Hammond $v$. Lenfest seems to have restored the doctrine's appropriate function in the legal process. As the absoluteness of the nonreviewability doctrine continues to wane, the exhaustion of remedies doctrine, applied as a discretionary measure to prevent premature review, should permit proper judicial consideration of the competing interests of the litigants. Because the profusion of military administrative channels continues to cause confusion in determining whether an alleged remedy is adequate, courts must examine such remedies carefully in making that determination. If the courts continue to show increased acceptance of functional stand-

262 Gallagher v. Quinn, 363 F.2d 301 (D.C. Cir.), cert. denied, 385 U.S. 881 (1966).

203 Robson v. United States, 279 F. Supp. 631, 633 (E.D. Pa. 1968), which states that military determinations may be upset "when the integrity of the fact-finding process has been destroyed by the gross lack of due process," id., citing Ashe v. McNamara, 355 F.2d 277 (1st Cir. 1965).

264 United States ex rel. Schonbrun v. Commanding Officer, 403 F.2d 371, 374 (2d Cir. 1968) (dicta), reconsideration of denial of stay denied, 89 S. Ct. 609 (1969).

205 Smith v. Resor, 406 F.2d 141 (2d Cir. 1969); Noyd v. Bond, 402 F.2d 441 (10th Cir.), non-incarcerated status granted, 89 S. Ct. 478 (1968), cert. granted, 89 S. Ct. 692 (1969).

266 Smith v. Ritchey, 89 S. Ct. 54 (1968); Fox v. Brown, 402 F.2d 837 (2d Cir. 1968), aff'g 286 F. Supp. 855 (S.D.N.Y. 1968) (dicta). 
ards for determining the applicability of both reviewability and exhaustion, the result should be less arbitrariness in military determinations and greater responsiveness of both military and civilian courts to protection of the rights of servicemen. 